\title{
From Practice to Field: \\ A Multi-level Model of Practice-driven Institutional Change
}

\author{
Michael Smets \\ Aston University \\ Aston Business School, Economics and Strategy Group \\ Aston Triangle \\ Birmingham, B4 7ET, United Kingdom \\ Tel: (0044) (0)121 2045262 \\ Fax: (0044) (0)121 2043306 \\ m.smets@aston.ac.uk.
}

Tim Morris

University of Oxford

Saïd Business School, Novak Druce Center for Professional Service Firms

Park End Street

Oxford, OX1 1HP, United Kingdom

Tel: (0044) (0)1865 288949

Fax: (0044) (0)1865 288805

e-mail:tim.morris@sbs.ox.ac.uk

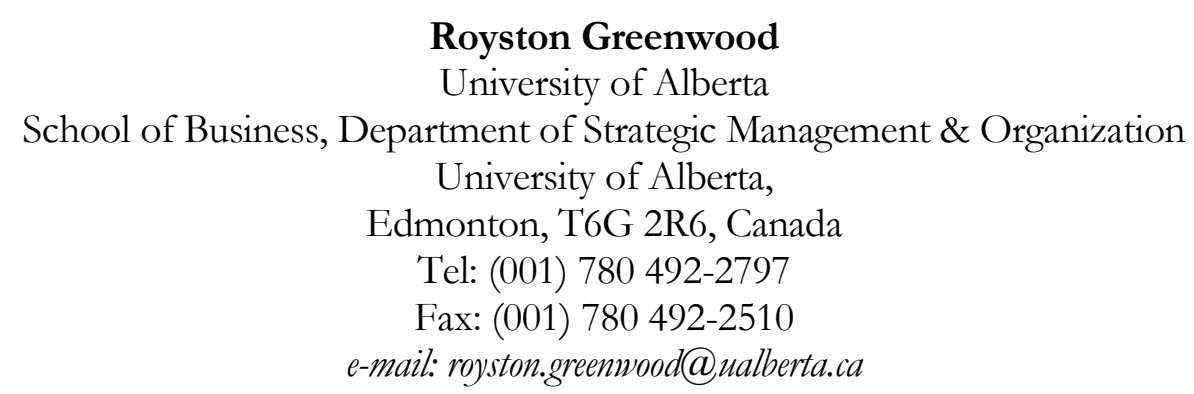

Acknowledgements: We would like to thank the editor, Mike Pratt, and the three anonymous reviewers for their insightful comments. We would also like to acknowledge the help we received from Paula Jarzabkowski and members of OTREG on earlier drafts, and the support of the Novak Druce Center for Professional Service Firms at the University of Oxford. 
FROM PRACTICE TO FIELD:

A MULTI-LEVEL MODEL OF PRACTICE-DRIVEN INSTITUTIONAL CHANGE

\begin{abstract}
This paper develops a model of practice-driven institutional change; that is, change that originates in the everyday work of individuals, but results in a shift in field-level logic. In demonstrating how improvisations at work can generate institutional change, we attend to the earliest moments of change that extant research neglects; and we contrast existing accounts that focus on active entrepreneurship and the contested nature of change. We outline the specific mechanisms by which change emerges from everyday work, becomes justified, and diffuses within the organization and field, as well as precipitating and enabling dynamics that trigger and condition these mechanisms.
\end{abstract}




\section{INTRODUCTION}

Understanding the processes and mechanisms of field-level change is a central theme in current institutional scholarship. In particular, there is increasing interest in how 'institutional logics' that structure behavior at the organizational and field level are disturbed and amended (Thornton \& Ocasio, 2008). To date, explanations of such changes have primarily emphasized field-level processes, involving deliberate institutional entrepreneurship characterized by conflict and contestation (Lawrence, Suddaby, \& Leca, 2009). But these accounts have been criticized for neglecting the micro-level origins and earliest moments of institutional change, prompting calls to pay closer attention to the unfolding of change as it arises from the day-to-day actions of individuals at work (Powell \& Colyvas, 2008).

We respond to these calls by studying how English and German banking lawyers in a newly formed international law firm sought to produce 'seamless' cross-border services and how their efforts interacted with field-level professional logics. We apply a 'practice' perspective (e.g., Jarzabkowski, 2005; Orlikowski, 1996; Schatzki, 2001) to develop a multi-level model of practicedriven institutional change which emerges from improvisations in everyday work, consolidates within an organization, and radiates to the level of the field. This model differs from existing theories and offers three contributions to our understanding of institutional change:

First, it shows how field-level institutional change may emerge from the mundane activities of practitioners struggling to accomplish their work, how it becomes rationalised at the level of the organization, and then moves to the field and instigates institutional change. The model is thus the first multi-level account of the interplay between institutional logics, organizations, and practices. Second, our model contrasts with existing accounts of institutional change not only in relation to the origin of the change impulse, but also to the process by which it unfolds. The model identifies three core mechanisms - situated improvising, reorienting the normative network, and unobtrusive embedding - and explains how they are triggered and how they operate. Notably, these mechanisms resist the 'search 
for drama' (March, 1981: 564) that characterizes other accounts of 'hypermuscular' institutional entrepreneurship (Lawrence et al., 2009: 1). We emphasize how the struggle and noise typical of other theories of change are replaced by a relatively quiet and unobtrusive process of diffusion that avoids regulatory pushback, increasing the likelihood of practice improvisations leading to institutional change. Third, we highlight the critical enabling role of organizational properties in mediating the emergence, justification, and diffusion of change. We show that organizational properties are important phenomena that influence how individuals experience institutional pressures and condition how practice improvisations extend to the level of the field.

Jointly, these insights show the value of incorporating the practice perspective into institutional analysis, but also advance this perspective itself. Practice theorists emphasize the connection of activities to wider systems of meaning, but, to date, empirical examples have remained at the level of the organization. This study is the first empirical multi-level account of the reciprocal relationships between micro-level practices and field-level logics.

\section{THEORETICAL CONTEXT}

\section{Existing Approaches to Institutional Change}

To date, three approaches to the analysis of institutional change have been proposed, each emphasizing differences in the origin, mechanism, and unfolding of change. The first and earliest approach portrays institutional change as resulting from exogenous shocks 'smacking into stable institutional arrangements' (Clemens \& Cook, 1999: 447). Such shocks include shifts in social values (Rao, Monin, \& Durand, 2003), regulatory policies (Edelman, 1992) or technological regimes (Garud, Jain, \& Kumaraswamy, 2002). By disturbing a settled arrangement, shocks enable actors to reflect upon the institutional logics ordering their world and to consider previously unthinkable possibilities. Studies within this approach have sought to understand why and with what effect actors can come to reflect upon taken-for-granted structures and act as 'institutional entrepreneurs' (DiMaggio, 1988: 14). A common prediction is that change will arise from the 'periphery' of a field 
because those organizations are less advantaged and less caught by prevailing institutional arrangements (e.g., Hensmans, 2003; Leblebici, Salancik, Copay, \& King, 1991; Maguire, Hardy, \& Lawrence, 2004; Rao, Morrill, \& Zald, 2000). Lounsbury (2002), for example, documents how new logics of investment and associated organizational forms arose outside the centre of the finance industry. Similarly, Thornton (2004) shows how entrants from other sectors carried new logics of business into the field of higher education publishing. Ansari and Phillips (2011) demonstrate how consumers, typically considered marginal players, catalyzed change in the communications sector. Accordingly, extensions of the exogenous shock model that shift attention from the locus of change to its mechanism and unfolding, draw on social movement theory with its imagery of 'power plays' (Rao et al., 2000) and 'institutional war' (Hoffman, 1999: 352) and emphasize open conflict and normative contestation.

A second, less developed account of change focuses upon the triggering role of endogenous field-level 'contradictions'. Seo and Creed (2002), following Friedland and Alford (1991), argue that the potential for change is inherent to most fields because tensions between contradictory logics intensify as fields mature. Organizations at the interstices of these tensions become able to consider different responses to institutional pressures, and to initiate change (e.g., Djelic \& Quack, 2003; Greenwood, Magàn Diaz, Li, \& Céspedes Lorente, 2010; Reay \& Hinings, 2005; Thornton, Jones, \& Kury, 2005). The resolution of endogenous institutional contradictions has been associated with rhetorical and political struggles (Greenwood \& Suddaby, 2006; Maguire \& Hardy, 2009; Maguire et al., 2004; Suddaby \& Greenwood, 2005). Accordingly, these studies focus on cultural codes, discourse and political skills deployed in mobilizing alliances (Lounsbury, 2007; Maguire \& Hardy, 2009; Weber, Heinze, \& DeSoucey, 2008). They show the tactics used to orchestrate collective movements (Den Hond \& De Bakker, 2007; Reay, Golden-Biddle, \& Germann, 2006) and spotlight the arenas in which they are deployed (Anand \& Watson, 2004; Garud, 2008). 
A third approach attends to the role of intra-organizational dynamics. Although implicit in Meyer and Rowan's (1977) idea of 'decoupling', the notion that organizational responses to institutional pressures are conditioned by intra-organizational interests and values has recently been elaborated by Pache and Santos (2010). The influence of intra-organizational interests and politics is also central to Edelman (1990) who highlights the filtering influence of senior managers in the adoption of macrolevel change, and to Dobbin $(1992 ; 2009)$ who shows the sense-making role of occupational groups. Similarly, Kellogg (2009) stresses the importance of 'relational spaces' within organizations to physically and politically bring together reformers seeking to implement top-down change initiatives.

An important contribution of this third approach is its recognition that organizational responses to institutional pressures can feed back to the level of the field. For instance, Edelman (1992) shows how legislation on 'due practice' required active interpretation at the local level which, in turn, encouraged development of the personnel profession which then elaborated and institutionalized the underlying logic. Similarly, Dobbin (2009) reconstructs how the logic of 'equal opportunity' came to be defined by personnel professionals in organizations, whose local 'translations' (Sahlin \& Wedlin, 2008) were then ratified at the field level. In all of these examples, however, it was field-level authorities that initiated and legitimated changes.

Collectively, the above studies have yielded important insights into why, where and how changes in institutional logics and their associated organizational arrangements might occur. They have identified field-level structural positions (Battilana, Leca, \& Boxenbaum, 2009) from which institutional entrepreneurs will arise, and have outlined their motivations. They have uncovered the mechanisms by which changes in logics are pursued, highlighting in particular the political and networking skills needed at both organizational and field levels. And they have outlined the contested ways in which insurgency or contradictions are theorized and resolved. 


\section{Critiques of Existing Approaches to Institutional Change}

Despite these advances, our current understanding of institutional change remains selective because existing approaches primarily adopt a macro level of analysis. The initiation of change is seen as a result of shifts in field-level structures that offer political opportunities to disadvantaged organizations or as the outcome of tensions and paradoxes that intensify as a field matures. Further, change is portrayed as a dramatic and highly contested process driven by 'organized and purposeful actors' (Ansari \& Phillips, 2011: 18) who 'skillfully use institutional logics ... in order to realize an interest that they value highly' (Leca \& Naccache, 2006: 634). Hence, although Thornton and Ocasio (2008: 119) state that institutional logics may get transformed 'through various mechanisms', the exigencies of everyday work have generally not been considered as one of them, leading Delbridge and Edwards (2008: 304) to conclude that what we have is but 'a simplified view of change'.

This relative neglect of such bottom-up change is surprising. Friedland and Alford's (1991: 249) original formulation defined logics as 'symbolic systems and material practices'. Thornton's (2004: 69) influential elaboration, similarly, saw logics as expressed in 'material practices, assumptions, values, beliefs and rules...' Moreover, it has been widely shown that improvisations occur in material practices as people invent, slip into, or learn new ways of interpreting and experiencing the world' (Orlikowski, 2002: 253). It has also been shown that such improvisations can result in significant organizational change (Feldman, 2000; Orlikowski, 1996). Importantly, for our purpose, the origin of such change is inherent in praxis, in the 'doing' of an activity, and it is the practitioner performing the activity who is its initiator. Some evidence is emerging that field-level change may also originate from 'individuals at the front line' (Reay et al., 2006: 979; see also, Chreim et al., 2007; Lounsbury \& Crumley, 2007), but there is no model of how such change moves to the field level.

In consequence, there have been repeated appeals that we should give greater attention to the micro-processes of institutionalization. Barley (2008: 510), for example, laments that 'institutions and actors meet in the throes of everyday life. [...] everyday life is institutional theory's coalface; [...] For 
over 30 years, the coalface has lain largely idle while institutionalists have sought their fortunes in the cities of macro-social theory. As a result, there is plenty of coal left to mine. What we need are more miners.' Similarly, Powell and Colyvas (2008: 276) urge for the exploration of how profound change might arise from the 'common sense routines of everyday life' because institutions and their underpinning logics 'are sustained, altered, and extinguished as they are enacted by individuals in concrete social situations'. Reaching the same conclusion, Hallett (2010: 56) cautions that 'If we do not attend to how institutional myths are coupled to actual work...our knowledge of how and why institutions matter is limited.'

\section{A Practice Approach to Institutional Change}

Recent work proposes the 'practice' perspective as a useful approach for attending to these appeals (e.g., Lounsbury \& Crumley, 2007; Whittington, 2006). Practices are patterns of activities that are given thematic coherence by shared meanings and understandings. Separately, these activities may appear trivial, but together they have meaning and order because of their common purpose and understanding of how specific activities should be done (Jarzabkowski, 2005). The practice perspective, thus, focuses not just on the doing of work, but on the 'shared practical understanding' which gives it meaning and makes it robust (Schatzki, 2001: 2). Further, those shared understandings, though 'local', are informed by broader cultural frameworks, i.e. by overarching institutional logics (Jarzabkowski, 2008; Lounsbury \& Crumley, 2007). Practices, in this sense, are the material enactments of institutional logics (Sahlin \& Wedlin, 2008).

This emphasis upon the work-level actions and interactions of individuals - and the understandings they reproduce and modify - suggests that a practice perspective is particularly suitable for connecting individual, organizational and institutional levels of analysis. It takes seriously the institutional context of agency and addresses recent critiques that much analysis has lost sight of the institutional framing of individual action and behavior (Delbridge \& Edwards, 2008; Delmestri, 
2006; Hardy \& Maguire, 2008). The practice perspective, in other words, is not simply about observing people at work; it respects the individual and what individuals do as socially constructed.

Interestingly, although studies of organizational practices show how the performance of 'real work' can result in organization-level change, the same studies have remained relatively silent on how practice-driven changes might occasion institutional change (Lounsbury \& Crumley, 2007). Mindful of this deficit, Whittington (2006: 617) has called for 'closer connections between what goes on deep inside organizations and broader phenomena outside'. In this sense, practice and institutional theorists occupy both sides of the same debate, each calling for engagement with the other.

In this paper, therefore, we show how everyday activity can be the locus for changes to practices that are anchored in field-level institutional logics. We specify the role of the mundane yet pervasive pressure to 'get the job done' as an underexplored origin of change and show the mechanisms by which such practice-driven change emerges from day-to-day work, consolidates within the organization, and may radiate to the level of the field to undermine the prevailing institutional logic.

\section{METHODS}

This study started from an interest in the complexity of cross-border professional work, sparked by the emergence of 'global' law firms around 2000. Intuitively, combining professionals from different jurisdictions in one organization should be problematic and put institutionalized local practices at risk of change. Hence, we entered the field with an open mind as to whether change would materialize and what form it would take (Suddaby, 2006).

\section{Research Design}

We use an embedded case study because it combines multiple data sources to capture the interplay of professional activities and logics within their organizational and institutional context (Stake, 1995). Our research site, dubbed Justitia, is a global law firm that emerged from an Anglo- 
German merger in the early 2000s to advise corporations, banks, and financial institutions on large international transactions. We chose Justitia's banking group as a 'particularly revelatory' case (Eisenhardt \& Graebner, 2007: 27), because here complex cross-border work is the rule rather than the exception. Its English and German offices provided the 'embedded' settings of our case. Embedded in two separate jurisdictions with distinct 'institutional legacies' (Morgan \& Quack, 2005), the two offices allowed us to study both sides of an institutional divide while eliminating organizational variation (see Pratt, Rockmann, \& Kaufmann, 2006). To appreciate the relationship of international work and local professional norms, we also gathered data on the field-level antecedents and responses to internationalizing legal practice.

\section{Data Collection}

We drew upon three data sources: observation, interviews, and archival materials to capture mundane activities, their ascribed meanings, and changes within and beyond the organization (see Table 1). We began with 12 pilot interviews to confirm the banking group and its Anglo-German interactions as an appropriate case. Then, we observed both the activities involved in completing cross-border banking transactions and the inter-jurisdictional negotiations over how these activities should be performed. Subsequently, interviews uncovered the meanings of specific activities. Finally, 'elite interviews' (Marshall \& Rossman, 1999: 113) and analysis of archival materials provided macrolevel data on the historical and institutional context of our observations.

Table 1 about here

Observation. Observation is suitable for micro-institutional research, because it focuses on individual actors and generates detailed insights into the minutiae of their work (see Jarzabkowski, Matthiesen, \& Van de Ven, 2009; Kellogg, 2009). Importantly, it captures 'behavioral patterns, but also the subjective experiences of organizational reality and the ongoing negotiations between members and subgroups over the interpretations and understandings of this reality' (Zilber, 2002: 237 emphasis added). Therefore, the first author spent approximately 13 hours per working day for two weeks in each of 
the two offices. He purposefully sampled 42 participants to cover all key transaction types and levels of seniority - especially 'partners' as practicing owners and 'associates' as non-partner professionals (Malhotra \& Morris, 2009; von Nordenflycht, 2010) - and focusing on lawyers working outside their home jurisdiction or on at least one Anglo-German transaction (see Table 1 for details). He shared their offices, attended meetings, listened in on calls, and joined social interactions during work breaks. German-born, but UK-based, the observer was culturally versed in both settings and fluent in both languages, enabling him to follow discussions without having to disrupt the natural flow of events for translation. Attending both work and social interactions allowed him to observe work practices in situ, and to clarify their rationales soon after.

The observer also attended two day-long workshops. The first, organized for Justitia's European banking specialists, discussed problems of cross-border collaboration and brainstormed 'best practice guidelines'. It provided a compressed introduction to the challenges and politics of interjurisdictional collaboration and revealed how lawyers justify their work patterns to each other. The second, organized for German law graduates, revealed how the banking group explained itself to newcomers and helped validate our emerging understanding of what banking lawyers do and why.

Interviews. In addition to the 12 pilot interviews, we conducted 55 semi-structured interviews to follow up on questions sparked by initial observations (Pratt et al., 2006). We first interviewed 31 of the 42 lawyers we observed at work, and 6 participants of the first workshop. We then followedup on respondent recommendations, interviewing another 13 snowball-sampled respondents, creating a total sample of 17 English solicitors in London, 16 English solicitors in Frankfurt and 17 German lawyers (Rechtsanwälte) in Frankfurt. Interviews lasted 30 to 140 minutes, were conducted in the interviewee's native language, tape recorded, transcribed, and, where necessary, translated into English. We asked interviewees to describe their work, specify challenges of cross-border transactions, and explain how these were being addressed. We prompted interviewees to identify changes in cross-border collaboration and explain how these related to their professional training 
and socialization. We also asked five 'elite' respondents to assess the plausibility of our emerging accounts of cross-border work and to set them in an historical and institutional context.

Archival materials. We had access to proprietary and non-proprietary firm-level documents that allowed us to validate impressions from observations and interviews (e.g., draft agreements, transaction schedules, client deal reviews, best practice guidelines, marketing or recruitment materials, client newsletters and websites). Further, we used textbooks and academic publications on law, codes of practice, training guidelines, and professional regulations to triangulate firm-level accounts with macro-level evidence of change in the organization and the field. We relied especially on publications of the English and German law societies (Law Society Gazette and BRAK-Mitteilungen), leading trade publications (The Lanyer and JUVE Rechtsmarkt), and, as our attention focused on more profound changes in the German field, the German Federal Bar's 2007 Report on International Law Firms (BRAK, 2007).

\section{Data Analysis}

In our inductive, open-ended analysis, we traveled back and forth between data, literature and emerging theory (Locke, 2001). In this process of gradual abstraction we categorized raw data, linked categories to themes, and aggregated them into a theoretical framework (Pratt et al., 2006).

We began coding by differentiating passages of text describing Justitia as an organization, its institutional context, and the work its lawyers do. We collated information on Justitia's size, status, history, recruitment strategy, transaction and client portfolio, on the legal and professional regimes in which its lawyers are trained and socialized, as well as on external constituents such as clients, counter-parties, syndicate banks, courts, and professional and trade associations that shape their work. We then picked out descriptions of work, using participants' own terms as in vivo codes (see Chreim, Williams, \& Hinings, 2007). We canvassed the full range of activities that make up the banking practice such as transaction structuring, negotiating, and drafting. We created a flowdiagram of how these activities connect on a typical banking transaction and, using NVivo's multi- 
coding function, identified the actors responsible for each activity and their jurisdictional affiliation. This diagram provided a map of inter-jurisdictional interfaces which required the transfer of work between lawyers from different jurisdictions. It highlighted the new complexity of cross-border work and focused our analysis on the process of 'germanizing'; i.e., a set of activities by which lawyers ensure that German and English documents connect seamlessly.

This map also formed the basis for our second phase of coding in which we cross-referenced existing codes and added another layer of coding so as to surface more abstract themes and uncover more or less implicit meanings, mechanisms and logics (Langley, 1999). This process was significantly helped by lawyers' tendency to explain their current ways of working in contrast to how they used to work or to how lawyers from another jurisdiction would work given their training and socialization. These cues of temporal and jurisdictional difference pointed us towards two 'scripts': The 'old story' in which traditional local practices prevailed and 'germanizing' was contested, and an emergent collaborative practice based on mutual adjustment and hybridization.

Following Barley and Tolbert (1997), we consulted alternative data in professional publications and legal textbooks to ascertain that observed jurisdiction-specific work patterns originated in professional socialization and to check that those changes which supposedly extended beyond Justitia were in fact institutional rather than organizational. Indeed, German professional publications associated the rise of international law firms with a shift in 'occupational image' or 'professional selfconception' in Germany, suggesting that change not only affected activities at work, but also their underpinning professional logic. Given the absence of such comments from English professional publications we focused subsequent field-level analyses on documentary evidence from Germany.

Having established the occurrence and institutional nature of change, we examined the data once more to better understand its origin and justification. We went back to our initial codes of important external audiences which cross-coded closely with pressures on, and changes in, working practice. Specifically, comments on the new complexity of cross-border transactions often occurred alongside 
descriptions of 'issue spotting', 'inventing fixes', 'working around' and 'pragmatism', grumblings that bankers put lawyers 'at the bottom of the food chain' when it comes to meeting their demands and deadlines, and statements, especially from the first workshop, that in a supposedly integrated global firm, inter-office disagreements 'just look bad'. 'Getting the deal done' was the phrase - repeated like a mantra - that connected these notions of complexity, crisis, and coping that drove lawyers' working day. We adopted this phrase for a cluster of themes including 'client pressure', 'cost of failure', and 'pressure to prove the viability of the 'global' firm' that seemed to drive experimental and localized adjustments to working practice.

Revisiting these initial codes also revealed that the courts were only one, and not even the most prominent, among many audiences being considered when assessing the merit of any 'fixes'. Professional bodies did not get any unprompted mentioning at all. Instead, there were plenty of references to 'appeasing rating agencies', doing everything 'with syndication in mind' and developments in other mega-law firms. It became clear that working around legal complexities was intertwined with discussions over which audiences mattered more or less in specific transactions. Lastly, cross-referencing codes on Justitia's status and market position with passages of text indicating change pointed to Justitia as an important transmitter of change. Using terms like 'leading' and 'cannot be ignored' to describe Justitia's position in the banking market, respondents emphasized how the increasing complexity of work forced them to change, but how their changes, in turn, forced others in the field to adapt.

To ensure the reliability and credibility of themes, we coded negative instances separately to assess their empirical prevalence. We triangulated them with documentary evidence or fed them back to key respondents for clarification. Multiple iterations between searches for explanations and for alternatives that questioned their plausibility produced increasingly refined themes that formed the basis for our final stage of coding. 
In our final step, we further aggregated and abstracted our thematic codes into a theoretical framework that encompasses the precipitating dynamics of change, the core mechanisms by which micro-level changes at work emerge and radiate beyond the organization, and a set of enabling dynamics associated with specific organizational properties. This step was facilitated by lawyers routinely using concepts and management terms in conversation, thereby unconsciously weaving theoretical signposts into raw data. We abstracted the pressures inherent in 'getting the deal done' as creating urgency and consequence, and connected these to the rise of novel institutional complexity as experienced in local practices colliding at work. We then linked urgency, consequence, and novel institutional complexity and identified them as precipitating dynamics. Using cues of transactionspecific 'coping', we engaged with the practice literature and abstracted situated improvising as a core mechanism of change. Likewise the themes of 'deciding who matters' and 'radiating change' through a practice network were abstracted into core mechanisms of reorienting the normative network and unobtrusive embedding. Lastly, a cluster of themes that emerged from descriptions of Justitia as an organization - such as the bureaucratic impulse of its 'one firm' status, its partnership structure, the special 'breed of people' it recruited, and its status - were abstracted into organizational coordination and institutional distancing. Table 2 summarizes our theoretical framework of precipitating dynamics, core mechanisms and enabling dynamics of change, empirical themes, and illustrative data from which they were distilled.

Table 2 about here

\section{THE CASE STUDY}

\section{Context}

The world of law is marked by significant cross-national variation that originates in the historical co-evolution of nation-state, law and legal profession (e.g., Halliday \& Karpik, 1998). National jurisdictions, such as England and Germany, have their own internally consistent professional 
structures and logics that are enacted in lawyers' working practice, i.e. in their role identity, key referent audience, and approaches to legal problems and drafting (see Table 3).

Table 3 about here

In Germany, law is codified in statutes which seek to strike a balance of interest between parties with different bargaining power (Avenarius, 1997). To maintain this balance, all lawyers are educated and qualified as judges and even lawyers serving clients in private practice 'must ultimately be committed to serving justice in a higher and more disinterested sense' (Keillmann, 2006: 311). Their claim to professional status hinges on their role as 'Organ der Rechtspflege' (agent in the administration of justice), and their enactment of a 'fiduciary' logic of professionalism (Thornton et al., 2005: 132). Their training focuses on academic legal knowledge and 'the expost evaluation of 'pathological' legal relationships, but not on future-oriented, creative practice' (Benda, 1981: 87), privileging socialization into the role of a technical specialist. Consistent with this socialization and qualification, the key referent audience for German Rechtsanwälte is the judiciary, which respondents describe as a 'duty to court'. It is in anticipation of court verdicts that they identify statutes that apply to a specific case and ensure contracts align with them. Hence, when confronting legal problems, German lawyers are predisposed to forensic analysis, examining whether, not how, a desired outcome can be achieved under the constraints of law. They draft slim documents with implicit recourse to codified statutes and only selectively signpost agreed deviations from non-mandatory norms (Avenarius, 1997).

English common law, conversely, is 'case law'. It is more piecemeal and affords more room for manoeuvre based on a strong doctrine of 'freedom of contract' (Halliday \& Karpik, 1998). It is the role of solicitors to utilize this space in their client's interest. Their work is guided by an ideal-typical 'expertise' logic (Brint, 1994). Solicitors enact this logic through their role as a business-oriented legal advisor, making 'the client's business [their] first concern' (Solicitors Regulatory Authority, 2007: 16). For them, the key referent is the client and, for banking transactions, the financial community. Their approach to legal problems is highly pragmatic and, in their drafting, they produce comprehensive 
documents that can easily reach several hundred pages for a single transaction, spelling out every clause and remedy.

Table 3 summarizes the differences between the ideal-typical professional logics of solicitors and Rechtsanwälte and their enactment in practice, which a respondent summed up as:

In the UK $[. .$.$] the solicitor dirties his hands a little bit more in understanding the client's business and$ trying to package a solution for the client. I think in a number of civil law jurisdictions ... they would be given a set of facts and they would give their academic legal opinion. And it feels more like you are being told what the answer is as opposed to discussing what a solution might be.

From 1990, Anglo-American law firms entered Germany in response to an increasing demand for advice on large-scale 'syndicated' lending ${ }^{1}$ and other sophisticated financial products they had created for their domestic clients. In contrast to the bi-lateral relationships of the traditional German Hausbank system, syndication provides finance through a network of banks. An 'arranger' negotiates terms and conditions for a loan and then repackages it for sale to syndicate banks or the financial market. In the process, rating agencies and various legal advisors are given access to - and comment upon - the original documents. An important feature of syndication is that loan agreements are typically governed by English law, but, under international law, collateral assets for a loan must be governed by the law applying at the location of the assets. This means that, for an English-law loan, secured on German assets, English and German lawyers must jointly ensure that any loan default clauses are enforceable under German law before documents can be passed on to a counter-party. This process - referred to as 'germanizing' by Justitia's lawyers - connects lawyers from previously separate jurisdictions and thus produces 'structural overlap' between their professional logics (Thornton et al., 2005). These inter-jurisdictional 'overlaps' are the focus of our study.

English firms eventually cemented their presence in Germany through a wave of cross-border mergers in the early 2000s. Notably, these firms sought to recruit 'cosmopolitans' and 'consulting

\footnotetext{
${ }^{1}$ Syndicated lending rose to prominence during the 1980s US and UK leveraged buy-out boom. It gained global relevance with new capital adequacy regulation that compelled banks to manage their credit risk and solvency by lending through a syndicate or by trading smaller portions of loans in a 'secondary loan market'. Europe lagged the initial trend, but by 2000 'took centre stage in the syndicated lending market' (Rhodes et al., 2004: 10).
} 
personalities' who, in the words of Justitia's senior partner, 'thrive on the international nature of assignments'; and having done so, provided them with sophisticated in-house legal training. Nonetheless, at the beginning of our study, global firms were underperforming relative to domestic rivals, calling into question the concept of the global firm (The Economist, 2004).

\section{The Collision of Local Practices}

Before the merger, and for some time thereafter, the 'germanizing' discussions were marked by a clash of professional practices and their underpinning logics. We observed and were told of difficulties in negotiations over the wording and format of contracts. Having to think 'beyond your own jurisdiction' introduced a complexity to lawyers' everyday practice which revealed a mutual lack of understanding. Lawyers on both sides complained that the others wore 'blinkers' and 'continued to do it the way...they had been brought up'.

English lawyers assumed that wide-ranging freedom of contract was a universal feature and expected German colleagues to circumnavigate obstacles to client goals. But German lawyers, trained to diagnose rather than solve problems, would respond in ways ridiculed by their English colleagues as providing a 'textbook of law' and often concluded that certain financial or legal structures could not be done because of the anticipated verdicts of German courts. This habit caused considerable frustration. One English partner, for instance, complained:

[They] are not prepared to think beyond what they know or think beyond what they have seen in the books. Whereas a British lawyer has been taught to think beyond just the law and how you can ... structure around issues rather than just saying 'can't be done'.

In these discussions, German and English lawyers prioritized different critical audiences, based on their professional logic and training. German lawyers, trained to think like judges, articulated inter-jurisdictional issues as legal issues, anticipated the verdicts of courts and maintained that some English-law concepts would not be enforced. Given their client-service logic, English lawyers 
considered the rejection of English-law concepts unprofessional and dismissed the forensic, lawfocused approach as unhelpful and unfit for meeting client demands. As one lawyer explained:

It is simply no longer good enough to know only the law. You have to be a lot more aware of the commercial circumstances. And you have to be a lot more solutions-orientated, I think. Your client doesn't really pay you as much as they pay [Justitia] to be told that they can't do something.

English lawyers tried to impose solutions and practices in a manner consistent with their pragmatic, client-focused approach and in the early months following the merger occasionally 'bullied' German colleagues to 'make it work'. Given their extensive academic training, German lawyers considered any questioning of their legal expertise by English lawyers as 'imperialistic'. They urged their English colleagues to understand that under the constraints of the civil-law system ‘sometimes it's just 'no'!

An instructive example of these inter-jurisdictional tensions occurred when a young German associate vented her frustration to her mentor in the corridor about an English colleague who had questioned her interpretation of German law:

There may be a point to solicitors working in Germany in finance, but then wanting to debate German law with us? Wanting to debate our CPs [Conditions Precedent]?

To which her mentor sarcastically replied: 'I'm sure [the solicitor] thinks: 'If it's like this in England, then it can't be much different in Germany'; or rather 'then it had better not be much different'.'

\section{Small Crises and the Pressure of 'Getting the Deal Done'}

These collisions of local practices in cross-border work were not without consequence. First, cross-border collaboration broadened the professional horizon of Justitia's lawyers, because 'just being aware that other legal systems do it differently just makes you more critical of your own.' Second, the repeated challenging of practices that lawyers on either side took for granted constituted small crises. One participant recalled how he had stopped a transaction because local-law concerns had been overlooked by English colleagues. Such instances, lawyers on both sides began to realize, did not inspire confidence with clients who showed little tolerance for disagreements among lawyers 
from the same firm. Justitia's claim that it could provide 'seamless' cross-border service, combined with its underperformance relative to domestic competitors, reinforced the pressure to 'get the deal done' and catalyzed a reaction, as one associate metaphorically explained:

If you keep two atoms in two separate test tubes they're never going to collide and make a new one, but if you put two atoms in the same test-tube and shake them around long enough, sooner or later they're going to collide and you get a reaction.

'Partners' in Justitia, as in professional service firms generally, are directly involved in service delivery and they were acutely aware of the costs of failure to deliver on time and on budget. They were also in a position to point these out to the associates (lawyers who are non-partners) with whom they worked. An example of this reinforcement was observed in a lunchtime conversation between ten associates who, fearful of missing transaction deadlines, were speculating upon the consequences. Quietly, the partner in their midst pointed out that transaction failure would lose the firm almost a million euros in fees. Half-amused at one associate's fear that this would be reported to 'management Europe', the partner pointed out that such a failure would inevitably be known to 'management global'. As a result, English and German lawyers came to understand that, as one German associate put it, they were 'at each other's mercy ... and somehow have to make it work'.

\section{Emergence of a Hybrid Practice}

Motivated by the pressure of 'getting the deal done' and enabled by a growing awareness and understanding of institutional alternatives, both English and German lawyers grew more receptive to alternative ways of working to cope with the complexities involved in 'germanizing' contracts.

Coping with complexity. Conceding that 'there is no point in drafting an English-law loan agreement until you understand the jurisdiction you are lending to', English lawyers pragmatically began to prepare transactions with an initial 'local-law due diligence' in an effort to pre-empt delays and frustrations. They switched from bullying to working with German lawyers in an attempt to understand 'what can and can't be done in respect of the German jurisdiction.' In response, German lawyers adopted the more pragmatic English approach, as a German partner put it: 
[When hitting a problem] you - metaphorically speaking - drive around it, jump across it, or dig underneath it - not to solve the problem, but to close the transaction.

German lawyers, in other words, began to re-focus their attention away from the letter of the law and towards the clients' interests. They rephrased the guiding question of their work to 'How do clients get to where they want to be - enforceable under German law?' and began improvising ways to 'translate the English concept - legal concept - into the local law'. They would draw diagrams and visualize intended outcomes to transcend legal terminology and help lawyers from both jurisdictions 'think together to find out what is commercially wanted and how it can be legally implemented'. In their drafting, they adopted the English approach of comprehensively documenting agreements, but eventually developed a hybrid format that would explicate key contractual terms and conditions in full and imply less critical terms and definitions with reference to German statutes.

Deciding 'who matters'. German lawyers also came to accept that, in order to expedite rapid transaction closure, the expectations of the financial market had to be prioritized over those of the courts. As one German associate recalled:

If you have to sell the German [variant] to the rating agencies and all other possible market participants who have never seen that before, that's difficult. Naturally, the line of least resistance is to take the English variant, rather than getting those documents back.

As this quote indicates, pragmatic adjustments implied a change in which field-level referents were prioritized. English lawyers emphasized that local-law concerns, the traditional focus of German lawyers, were less pressing. They pointed out that, in their experience of international transactions, the likelihood of going to trial was very low because contracts were drafted such that any disputes could be resolved through recourse to private agreement, and reliance on courts was minimized. Therefore, it was referents in the financial world, such as rating agencies and syndicate banks, who were the more significant because it was them who would affect the viability of a transaction. Hence, over time, as the German lawyers adopted the English approach, they re-focused their attention towards their clients and the expectations of syndicate banks and rating agencies. 
This shift towards prioritizing of financial over legal referents was stimulated by the continuous and animated urging of clients. Day-to-day drafting, researching and reviewing were constantly interrupted by phone calls and email requests from clients expecting an immediate response. While this was the norm for English lawyers, it was a novel experience for the German lawyers, as a young associate vividly demonstrated: '[Clients] are constantly on your back: 'Do this, do that, we want this, we want that.' And you go 'AAARRGH' [she mimics being strangled].'

Clients were also given voice by Justitia's process of soliciting formal client reviews, which highlighted how critical clients were of poor inter-office management, of 'academic legal debates' and of the resultant delays and cost overruns. By contrast, clients valued 'integrated teams' that had an 'understanding [of] differences between regimes and cultures', the 'ability to meet stringent and even unrealistic deadlines' and that were 'prepared to compromise for the purpose of moving ahead'. These reviews, shared among all of the lawyers involved, were known to matter for the quality of future assignments and career progress. The story of a young female partner in the Frankfurt office, who had successfully won an important client account from the London office, became part of office lore. As one associate described the story:

We have a partner here who works a lot for [investment bank]. Formerly, [investment bank] would never have mandated Frankfurt directly. It always went through London. And then they got to know this partner on a couple of transactions and were very enthusiastic. And now she's being instructed directly. That's how it works.

Similarly, role models who delivered transactions in close collaboration with juniors showed how joining an international firm and adopting its practices provided, as one Partner noted, 'an opportunity for German lawyers to establish themselves and participate in the global market'. Justitia's German lawyers were particularly well-placed to take this opportunity because cross-cultural experiences during studies abroad and/or previous employment in consulting or accounting firms made them more 'cosmopolitan' and thus open to alternative ways of working. One German lawyer reflected on how far this shift in practice had changed him and his colleagues:

Now the German law firms and the German lawyers have got that mentality, so now we come with a self-conception that we solve the problem or [that] we have a toolkit we can work with and we can achieve what the clients want. [...] And this mentality has certainly come from the internationalization of the legal 
market here [in Germany].

\section{Consolidating the Hybrid Practice}

At any one time, Justitia would be engaged in multiple banking transactions, each the responsibility of a small team whose members had high discretion. Initially, therefore, improvisations bubbled up in multiple locations as and when transaction teams encountered specific problems. Overlapping memberships of these teams, however, acted as natural conduits for the diffusion of the emerging practice and connected the dispersed pockets of awareness. Moreover, because they were inevitably working under significant time pressures, lawyers began to re-use previous improvisations, and to adopt particularly successful improvisations as they learned them from their colleagues.

Relatively quickly, however, this pattern of haphazard, distributed improvisation and adaptive learning began to be pulled together, significantly helped by lawyers being part of the same firm especially in the Frankfurt office where they were co-located - to the point where the banking group became recognized as one of the most integrated groups in the firm. The lingua franca of doing deals' was shown, literally, in the common language that lawyers used. Despite English being the official office language, German lawyers would address English colleagues in English, who would then respond in German. Likewise, German lawyers seamlessly adopted Anglicisms, such as 'germanizing', and their English colleagues would insert German legal terms into their Englishlanguage memos to ensure a common understanding. In one instance, a senior associate who had previously been seconded to Frankfurt read up on German law in preparation for a call with her former colleagues and then switched into German for a discussion of which combination of civillaw concepts would get the client closest to his intended outcome.

Partners, aware (and often creators) of the various practice-level improvisations, began to systematize them in order to capture a more organizationally efficient approach. An on-line tool was created to help spot legal inconsistencies between jurisdictions and a program of inter-office 
secondments was begun. Eventually, in 2005, a workshop was held to codify 'best practice guidelines' and the client-service focus was documented in a firm-wide memo, urging lawyers to:

Find out what [clients] want and need and give it to them, consistently, time after time, with the appropriate availability to do so - If we don't do this, another firm will.

Although adjustments continued to eradicate the remnants of old practices, this codification was a pivotal event in formally endorsing the new practice. As one associate put it: 'This is something every lawyer should read and abide by. It's the foundation of our practice.'

It is worth emphasizing that the new hybrid practice, outlined in table 3, was not laid down at the outset but emerged from efforts by practitioners to cope with the new complexities and pressures of their international work. In the words of one respondent: 'The legal system, the legal training, doesn't necessarily play the crucial role here. I mean, everything is being glossed over at work!' The hybrid practice blended activities from both jurisdictions and introduced some new ones but, critically, oriented them towards realizing client interests. They produced, in German lawyers' view, 'a completely different concept of Rechtsanwalt in which client service displaced the traditional fiduciary logic, because: 'At the end of the day if I don't make my client feel he is getting value for money and added value from what I say, then why use me? He can use anyone else.'

\section{Radiating from Practice to Field}

At the field level, Justitia primarily interacted with its clients - i.e., banks providing finance. Justitia also interacted with other elite law firms representing the corporations seeking finance and law firms advising other banks in the lending syndicate. These interactions regularly drew on standards set by international trade associations in which key players, such as law firms, banks, consultants, and rating agencies, develop best practices and codify private standards for the syndication of international loans. The legal work drawing on these standards occurred under the regulatory oversight of local law societies, such as the German Bundesrechtsanwaltskammer (BRAK). 
Initially, within this context, the new practice diffused naturally through the repeated interactions within this small elite network of firms engaged in international banking transactions. In this elite network, firms watched and learned from each other and aligned their practices in order to expedite deals. As we were told:

The mechanism is such that on one big transaction it gets done and for the next one you already have a template. [...] That's how change creeps in.

This 'creeping' change was reinforced by the practice of syndication itself, giving a wider network of syndicate banks and their law firms access to the relevant documentation, which reflected practice changes. But transactional work also carried these changes beyond this elite network:

When we end up on transactions with midsize German firms who clearly don't have the experience of finance documents and don't know how and what they should be doing, I waste my fee cap educating them.

Whether change was attributed to the 'creeping' standardization of new transaction templates or more active 'education', Justitia's 'leading' status was considered a critical enabler of change, assuring other market participants of its appropriateness:

And when Justitia takes such a clear position, then I do think that that has an impact, because it repeats itself in deal after deal after deal. And you've got a name, you got size [...] a smaller firm or the competition may think: 'Well, look, Justitia ... they would never give careless advice.' That's how I would say markets are influenced.

It was by being involved in transactions, in other words, that firms learned of the new practice; and, it was the pressure from clients that motivated them to adopt them. Justitia was fully aware of how it and other elite firms were changing professional behaviors:

We are influencing the market by our practices, which is making our competitors also need to change, because the clients are saying: 'You're not doing it like we like it and we know we like this and that, because [ustitia] does it'. So they're changing in some cases to be like us.

\section{Endorsing a New Logic}

Hence, what had begun as a practice-level change, localized within high-status firms, radiated more widely. It did so in a relatively unopposed manner because of the distant relationship between, on the one hand, highly specialized international firms and, on the other, the main body of the German legal profession and its professional association, BRAK. 
The international firms, such as Justitia, knew that it took 'very, very deep insight into what we are doing to engage with it' and that BRAK lacked the resources and mandate to do so:

I think they do exercise a degree of control [...] or at least they attempt to regulate what can and what can't be done. But without really going into the business it's more a question of, [...] dealing with conflicts of interest, and the ability of non-German lawyers to practice in Germany.

Aware that their internal practices were shielded from inspection, international law firms did not consider BRAK relevant, especially compared to their peers whom they considered more relevant for how they conducted their business. Hence, instead of engaging with their local professional association, international firms like Justitia played a prominent part in international trade associations, such as the Loan Market Association, the International Swaps and Derivatives Association or the True Sale Initiative, that were setting private standards for the financial community.

On BRAK's part, interest in international law firms was complicated by the structure of its membership. The Anglo-German merger wave had sparked a fear of 'foreign infiltration' amongst BRAK's main constituents - small firms and sole practitioners. But the rise of international law firms was also considered an opportunity for the German legal profession which had initially slept through the international development', giving Rechtsanwälte access to new markets, and increasing their global prestige (BRAK, 2007: 10).

Hence, in response to the worries of its main constituents, in 2001 BRAK instigated a small 'Working Party on International Law Firms' staffed with a mix of lawyers from small and medium firms, professors of law specializing in constitutional, professional and public law, representatives of regional Bars and BRAK, and partners from large and international firms, albeit from 'traditional' areas outside banking. It was asked to do three things: to conduct a 'fact finding mission' into the 'internal modus operandi' of international firms; to establish whether international firms were conforming to the conventional image of the Rechtsanwalt as an 'agent in the administration of justice' as encapsulated in the profession's core values; and to engage international firms in dialogue. 
Lacking resources for a systematic and large-scale survey of the sector, the Working Party confined its 'fact finding' to the personal experiences of its members. In consequence, the enquiry did not penetrate to the working practices deep inside the international firms, but instead turned its focus to a legal analysis of visible practices such as advertising, recruitment, forms of incorporation, the management of conflicts of interest, and their compliance with professional law. At this time, a series of legal disputes over these visible practices revealed that pushing back the international firms would be extremely difficult. In response to what industry commentators described as an 'uncontrollable erosion of national professional laws' at the hands of international law firms, BRAK's later President, and a Working Party member, thus realized that in dealing with international firms:

Flexibility is of the essence! ... If professional law does not take into account the legitimate interests of ... [the international firms], it will sooner or later be overthrown ... Once a norm is overthrown it no longer applies to anyone... It would be irresponsible to jeopardize the profession's autonomous rule-setting authority in this way.

By the time the Working Party entered dialogue with international firms in 2005, broader trends in the profession complicated BRAK's relationship with the international firms, and the perceived need for 'flexibility' was exacerbated. As evidenced in discussions of the 'Clementi' reforms in England and the proposed new German Legal Services Act, there was growing concern over the opening up of legal services to competition from non-lawyers and the preservation of professional privileges. This concern for the interests of the entire profession coloured BRAK's attitude towards international firms. Although the Working Party's final report is relatively silent on some of these pressures, publications by Working Party members and high-ranking BRAK officials strongly suggest that they played an important role in the Working Party's deliberations.

Unable to successfully challenge international law firms in court, BRAK also realized that admitting that the practices of international firms contravened the traditional German professional logic would raise the question of whether the legal profession per se still merited its monopoly and right to self-administration, if large parts no longer adhered to the public-service ideal that 
underpinned them. Therefore, in the interest of avoiding the loss of professional privileges, from which small and medium-sized firms would suffer disproportionately, BRAK found it necessary to present a 'united front' against outside challengers. BRAK's president urged his members not to dismiss the unity of the profession as 'some romantic argy-bargy', but to embrace it as a 'compelling necessity to fend off attacks on our integrity and power.' Hence, having initially treated international law firms as a marginal issue, by 2007 BRAK found itself having little choice but to co-opt them.

Therefore, to preserve existing professional privileges, the Report of the Working Party downplayed any deviation from traditional ideals by stretching the fiduciary logic reflected in the role of 'agent in the administration of justice'. The Report concluded that by serving a previously neglected segment of clients, international law firms were still working within the principles of the fiduciary logic. However, the Report also explicitly acknowledged international firms' locomotive function' in changing the self-conception of the profession, applauded their commercial orientation, and embraced the role identity of the German Rechtsanwalt as a 'special kind of entrepreneur'. In effect, the Report endorsed the client-service logic.

This logic shift was not limited to the small circle of international law firms, but concerned the entire profession, as reflected in new federal statutes. The Legal Services Act (2008) also endorsed the new logic by emphasizing the role of legal service to clients. Legislative commentators noted that the Act 'terminologically departs significantly' from previous versions 'by introducing legal service as a key term' (Deutscher Bundestag, 2008: 2). This terminological shift codified the shift in the German lawyer's occupational image - or logic - to cover the broadened scope of legal services and their increasingly proactive and client-centred commercial orientation.

\section{TOWARDS A MODEL OF PRACTICE-DRIVEN INSTITUTIONAL CHANGE}

Our case study suggests a model of practice-driven institutional change - summarized in Figure 1 - that connects practice, organization and field, and that traces how institutional change arises not 
from a single but a 'concatenation' of mechanisms (Tilly, 2001: 24). In this section we explain this model, showing, first, that when three precipitating dynamics - novel institutional complexity, urgency, and consequence - are jointly experienced in everyday work, they activate a chain of core mechanisms that span individual, organizational and institutional levels. We label these core mechanisms situated improvising, reorienting the normative network, and unobtrusive embedding. We also identify two organizational properties - the impulse of organizational coordination and the capability for institutional distancing - that enable and amplify the effects of these core mechanisms.

Figure 1

\section{Precipitating Dynamics}

The idea that change occurs because 'most of the time most people in an organization do what they are supposed to do; that is, they are intelligently attentive to their environments and their jobs' (March, 1981: 564) is a central tenet of practice theory. However, small adaptations typically produce 'convergent change' within the parameters of an existing logic (Greenwood \& Hinings, 1996: 1024). By contrast, whenever individuals associate 'the everyday contingencies, breakdowns, exceptions, opportunities and unintended consequences' (Orlikowski, 1996: 65) that surface at work with the institutional anchoring of their practice, practice adaptations can become 'radical' and unseat an existing logic's 'archetypal template' (Greenwood \& Hinings, 1996: 1026). Our study thus complements studies that have shown how organizational change can arise from slippage in routines. We explicitly examine changes to a practice that is anchored in an externally legitimated archetype. Extending March's (1981) argument to the institutional level, we argue that it is the occurrence of a work-level crisis that precipitates practice-driven institutional change.

A crisis, following Hermann's (1963) seminal definition, has three elements: surprise, a short decision time, and a perceived threat to high-priority goals. At the practice level, we find these elements represented in the encounter of novel institutional complexity, the urgency of accomplishing 
work, and the consequence of failing to do so. It is the combination of these elements that constitutes a work-level crisis and thereby precipitates practice-driven institutional change.

Novel institutional complexity. Institutional complexity refers to the co-existence of two or more logics whose prescriptions are experienced as incompatible. Such experiences engender surprise and the reflexivity associated with embedded agency (Battilana \& Dorado, 2010; Dorado, 2005; Greenwood, Raynard, Kodeih, Micellota, \& Lounsbury, 2011; Greenwood \& Suddaby, 2006; Seo \& Creed, 2002). Viewing this problem through a practice lens highlights that it is through engagement in the 'doing' of work that logics are instantiated and by which any incompatibilities become problematized. Hence, in contrast to existing accounts that locate institutional complexity in field-level 'contradictions' (Seo \& Creed, 2002), novel institutional complexity is experienced as 'part of the ordinary, everyday nature of work, rather than exceptional phenomena' (Jarzabkowski et al., 2009: 289).

Importantly, it is not the existence of institutional complexity per se that precipitates change, but the novelty of this complexity, for, as recent accounts suggest, organizations can accommodate competing logics in various ways (Binder, 2007; Pache \& Santos, 2010; Reay \& Hinings, 2009; Tracey, Phillips, \& Jarvis, 2011). Over time, contradictions are resolved and new arrangements and practices become relatively 'settled' (Rao \& Kenney, 2008). It is the encounter of novel complexity that makes practitioners reflect and step outside existing arrangements to search for new accommodations.

As shown in our case, novel complexity can arise as practitioners - as carriers of different logics are brought into contact through the exigencies of their work, as illustrated in Figure 1 by the connections between field-level logics, the 'collision of local practices' and precipitating dynamics. This occurrence is not to be confused with an exogenous shock, because this new complexity is of practitioners' own making. The connection of different ways of working, the sensitivity to the lack of 
'sharedness' of understanding, and the awareness of institutional alternatives associated with embedded agency all flow from practitioners' engagement in practice.

Urgency. By itself, the experience of novel institutional complexity can generate 'polarization' (Jarzabkowski et al., 2009: 298) between carriers of different logics. When, however, the surprise of novel institutional complexity is combined with the urgency of tight deadlines and with costly consequences of failing to negotiate agreement, the situation escalates into an autogenic, work-level 'crisis' (Hermann, 1963). It is this sense of crisis which overcomes entrenchment and precipitates practice-driven change. For example, Kellogg and colleagues (2006) observed in an advertising agency that professionals would pragmatically adopt intermediate rather than optimal solutions simply to maintain work progress in the face of tight deadlines.

When the complexities stalling work progress are institutional, however, urgency catalyzes change by 'convening' carriers of different logics - who, as in our case, realize that they are 'at each other's mercy' - and become motivated to engage in collaborative arrangements that 'jumpstart' institutional change (Dorado, 2005: 386; see also, Lawrence, Hardy, \& Phillips, 2002). Importantly, practitioners convene around the resolution of practical problems in the present, rather than some future institutional vision (Emirbayer \& Mische, 1998). In this sense, urgency undermines normative grandstanding and injects negotiations over which - and how -competing logics are to be enacted with a distinctly pragmatic dimension (Heimer, 1999). This pragmatism favors improvisations that account for the situation at hand as a mechanism by which novel institutional complexity is addressed and change initiated.

Consequence. A sense of urgency is particularly pronounced when the failure to resolve novel complexity by a given deadline is fraught with consequence. Lawyers within Justitia, for example, could not remain entrenched in their inherited practices if they were to satisfy clients and accommodate pressure from seniors to deliver on the promise of the 'global' firm. They had to spontaneously reconcile or prioritize contradictory practices in order to avoid the financial and 
reputational cost of failing to 'get the deal done' on time and budget. Similar dynamics were reported by Heimer (1999) from her study of neonatal intensive care. By contrast, Kellogg (2009), in her study of top-down change in a hospital setting, did observe entrenchment. We suggest that this was because patients in a non-critical state cannot create the kind of urgency and consequence of failure imposed by the powerful clients in our case, or the emergency situations in Heimer's (1999) study.

This observation - that under specific conditions novel institutional complexity leads to pragmatic improvisation - is especially interesting given that we studied professionals who are typically regarded as exemplars of normatively conditioned actors (DiMaggio \& Powell, 1983). Our case is thus a strong indication that, in situations of institutional complexity whose resolution is urgent and fraught with consequence, appeals to higher-order values (e.g., Maguire \& Hardy, 2009) give way to pragmatism. In effect, the crisis-like precipitating dynamics of novel institutional complexity, urgency and consequence condition the core mechanisms by which practice-driven change emerges, is justified, and diffuses.

\section{Core Mechanisms}

Situated improvising. The generative mechanism for change in our model is situated improvising, i.e. localized attempts to cope practically with novel complexities and accomplish specific tasks (Orlikowski, 1996; Tsoukas \& Chia, 2002). In contrast to the 'institutional design' of institutional entrepreneurs (Hargrave \& Van de Ven, 2006: 867), situated improvising is distributed rather than focused and experimental rather than carefully planned (Lounsbury \& Crumley, 2007). The locus of change is the practice and the 'entrepreneur' is the practitioner at work.

Practitioners only act as institutional entrepreneurs, however, in that their situated improvising may break with the dominant logic in the field, but not in the sense that they deliberately intend to unseat existing institutional arrangements (Battilana et al., 2009). Instead, the situatedness of their improvising, reinforced by the urgency of the situation prioritizes coping with complexity. Hence, situated improvising generates institutional change that is 'accidental' in Plowman et al.'s (2007: 518) 
sense of being propelled by a 'pattern of adaptations that is frame-bending' and being 'emergent and systemwide as adaptations accumulate, but not in the sense of accumulating in a random and serendipitous fashion that others suggest (Barley \& Tolbert, 1997; Lounsbury \& Crumley, 2007).

Institutional change that emerges from situated improvising, in other words, is not strategic, but it is not entirely unintentional either. This observation is consistent with Dorado's (2005: 389) prediction that in situations of complexity or uncertainty, actors for whom 'the present is the dominant temporal orientation $[\ldots]$ are not expected to follow routines and cannot undertake strategic projects'. Instead, its situatedness in practice means that improvising is not motivated and coordinated by institutional strategizing for the future, but by the common purpose of 'getting the job done' in an institutionally complex present.

In consequence, the process of its unfolding is distributed and non-linear, as localized adaptations are conceived and tried. However, as diffusion is a function of being involved in the practice and legitimation occurs partly from the rippling spread of improvisational efforts, the accumulation of small changes is not random. As experiences accumulate, more standardized arrangements come into focus as practitioners learn from their vantage point in the practice as to what works and what does not.

Situated improvising, then, involves the search for new ways of carrying out specific activities within a practice. But, as a practice also embodies meanings and understandings, changes in activity implicate those meanings and understandings that stabilize established practices. Hence, situated improvising that departs from the parameters of a prevailing logic occurs alongside a second core mechanism that addresses these normative elements of practice: reorienting the normative network.

Reorienting the normative network. Reorienting the normative network involves the foregrounding and prioritizing of specific 'referent audiences' (Greenwood et al., 2011). All institutional logics imply the importance of particular audiences who deploy and endorse behaviors 
prescribed by a given logic. For example, Thornton's (2004) editorial logic highlighted the role of editors, their contacts with authors, and family owners. In contrast, in the same industry deployment of the market logic gave emphasis to CEOs, corporations and shareholders. It is thus by referring and pointing to particular audiences that practitioners implicitly express the logic guiding their assumptions of appropriate conduct. Further, to the extent that particular audiences are foregrounded in work-place discussions it is 'their' logic that prevails. Faced with novel institutional complexity, therefore, practitioners negotiate their normative network by foregrounding and giving voice to particular audiences, while silencing or subordinating others. They establish 'who matters' and, by implication, whose logic should apply. The narrowing of the network serves the same purpose as Kellogg's (2009) 'relational spaces', in that it shields an emerging practice from institutional discipline by removing representation of one set of institutional prescriptions and concentrating scrutiny among members of the practice community.

Normative reorientation is a practice-level variant of 'theorization' (Greenwood, Suddaby, \& Hinings, 2002; Strang \& Meyer, 1993) by which existing arrangements and practices are 'disassociated' from their 'moral foundation' (Lawrence \& Suddaby, 2006: 236) and by which situated improvisations are justified. Importantly, however, this practice-driven justification mechanism differs from theorization as it has been used at the field level in several ways.

First, the 'disassociation' of an existing practice from its moral foundations occurs by separating its evaluation from those referent audiences that represent its underpinning logic. Normative reorientation shields the emerging alternative from the application of institutional discipline and buffers the social risks involved in breaking with the prevailing field-level logic. This mechanism resonates with Kostova et al.'s (2008: 1002) hypothesis that multinational organizations confront institutional complexity through 'simplification processes', but contrasts with social movement theories that emphasize the broadening of audiences as a prerequisite of change (Schneiberg \& Lounsbury, 2008). 
Second, given the implication of field-level logics in practice improvisations, change is not being justified after the development of a recognizable new practice, but alongside its emergence. In contrast to planned institutional change, in which entrepreneurs first define a project and then 'bargain for support and acceptance from external constituencies' (Dorado, 2005: 389; see also, DiMaggio, 1988), situated improvising, and its justification by reorienting the normative network, are interlinked. They accumulate and co-evolve simultaneously, as represented by the clustering and circular relation of both mechanisms in Figure 1.

Third, this variant of theorization does not involve the commonly reported explicit process of abstraction, normative justification and open contestation (e.g., Anand \& Watson, 2004; Brint \& Karabel, 1991). In practice-driven change, there is neither time nor need to appeal for the interventionist support of field-level authorities. In a narrowed normative network that centres on practitioner peers, pressure for change is experienced in praxis and the pragmatic efficiency of an improvisation is evident for those practitioners concerned with the specific problem. While Maguire et al. (2004: 669) state that reformers must 'theorize political chains of cause and effect' to demonstrate the cost of not changing, the cause-effect chains that practitioners construct are not political but pragmatic. Therefore, in contrast to Maguire and Hardy's (2009) proposition that processes of deinstitutionalization primarily involve contested normative appeals and the political mobilization of affected interests, practice-driven change is highly pragmatic, not political.

In sum, the situated nature of practice-level improvisations entails that the mechanism of their justification (reorienting the normative network) differs from existing concepts of theorization in that it occurs alongside, rather than after, the emergence of a new practice. It focuses on the justification of a solution, rather than the framing of a problem, and aims at persuading a narrow practitioner community, rather than a variety of audiences, of the pragmatic benefits of change.

Unobtrusive embedding. As depicted by the vertical arrangement in Figure 1, situated improvising and normative reorienting are particularly salient at the level of the practice and 
organization. Our third core mechanism, in contrast, applies at the level of the field. This mechanism - unobtrusive embedding - causes a change in practice to radiate beyond the organization to effect change at the level of the field. The distinctive feature is that this embedding occurs in a relatively unobtrusive manner.

The key conduit by which situated improvisations 'eventually trickle up' to the field (Quack, 2007: 643) is active participation in the practice itself. This observation - that diffusion and cognitive legitimation occur through the interactions of professionals engaged in work practices - extends Dobbin's (2009) thesis that ideas move through the associational communities of professionals. It also offers an alternative to the more common view that ideas and behaviors move between organizations through executive migration (Kraatz \& Moore, 2002) or board interlocks (Zajac \& Westphal, 1996), or are 'carried' by management consultants and the media (e.g., Sahlin-Andersson \& Engwall, 2002). But more importantly, it means that the justification of small changes by reorienting the normative network creates preconditions for the diffusion of change through unobtrusive embedding. Practice-driven change can become embedded without the loud appeal or use of rhetoric by disaffected actors seeking to mobilize support for change (Hardy \& Maguire, 2008); that is, its diffusion lacks visibility among non-practitioners.

Visibility implies that issues and proponents are more easily recognized and rebuffed, or at least stalled and delayed. Lounsbury and Crumley (2007; see also, Plowman et al., 2007) recognized this link and noted how new money management practices initially diffused without field-level attention or resistance, but that once they gained visibility they were stalled because of contestation from the 'old guard'. Practice-driven change, in contrast, diffuses quietly - and without dramatic events through the engagement of practitioners 'doing work'. The 'issues' driving practice-driven change are inherent in everyday work, they are typically small, and are deployed within a private network of interested actors. 
The implication, paradoxically, is that the highly localized, pragmatic improvisations of practicedriven change may be harder to resist than the more visible actions of identifiable institutional entrepreneurs, especially those that involve rule-based changes such as new laws (Quack, 2007)². because they avoid the attention of regulators and potential resistors until they have become relatively pervasive 'proto-institutions' (Lawrence et al., 2002). Practice-driven improvisations occur under the regulatory radar and develop in an apparently loosely coordinated manner, and do so without attracting attention. Thus, the low visibility and unobtrusiveness of embedding at the level of the field also creates favorable conditions for further improvisations and justifications at the level of the practice and organization, as illustrated by the downward feedback loop in Figure 1. By the time potential resistors perceive these accumulated improvisations and realize their effect on the previously dominant field-level logic, they are more difficult to dislodge (Plowman et al., 2007). This effect is exacerbated if, as in our case, the position of potential resistors or regulators vis-à-vis proponents of change is weak at the time of discovery due to differential resource endowments or an inability to mobilize effective opposition.

\section{Enabling Dynamics}

One of the key points of our model is that practice-driven change is significantly advanced by the location of a practice within rather than across the boundaries of an organization. Bringing the practice inside an organization opens it up to enabling dynamics that affect the speed at which improvisation will consolidate and then radiate to the field. We advance two important 'enabling dynamics' (Greenwood \& Hinings, 1996) - the impulse of organizational coordination and the capacity for institutional distancing - and show how the organizational properties that underpin them encourage the emergence, justification and accumulation of small adaptations.

\footnotetext{
${ }^{2}$ An important difference with the work of Quack (2007) is that Quack attends to changes in law, i.e. rule-based changes, that must be authoritatively ratified to take effect. Hence, she observes a second, more strategic stage of field-level legitimation that necessarily involves national or transnational authorities and professional associations. The norm-based change in practice that we observed, by contrast, did not require such ratification and accordingly, change was embedded further and the legitimating role of BRAK more post-hoc than what Quack finds.
} 
Organizational coordination. Organizations by their very nature seek collective order through coordination of their processes and routines (Thompson, 1967). Although a mosaic of overlapping yet uncoordinated situated improvisations may initially be tolerated and even encouraged, the impulse to coordinate will be stronger inside an organization. In this sense, coordination is the pulling together of distributed improvisations and their formalization into policies and rules that describe and prescribe the new practice and, by implication, prioritize the importance of one logic over another. It serves to legitimate and diffuse accumulating improvisations within the organization and enables further change and consolidation (see Plowman et al., 2007). The allocation of resources to such coordination exercises and the development of a 'common language' for discussing change are then facilitated.

The effect of coordination, however, is more than the formalization of situated improvisations. Coordination also means that practitioners work under the same organizational strategy and share the realization that they, and their careers, are implicated by that strategy's successful implementation. Any behavior that would polarize and disrupt implementation has to be avoided, increasing the pressure to resolve institutional complexities quickly and helping professionals accept mutual dependence and the need to work together (Chreim et al., 2007). Further, professionals in the same organization interact more regularly as they participate in multiple iterations of the same practice, learn of more efficient practices, and develop trust (Kramer \& Lewicki, 2010).

In Justitia, coordination was enabled by both vertical and horizontal connections. Vertically, the involvement of senior professionals in the practice itself allowed them to learn of 'frontline' tensions arising from novel institutional complexity, and to show by example - and thus legitimate - the reprioritization of audiences that facilitates their resolution. It also made senior professionals aware of the unfolding variety of improvisations occurring at the practice level and alerted them to the need for organizational coordination. Horizontally, coordination was enabled by lawyers participating in overlapping teams, enhancing both diffusion and legitimation of effective improvisations. 
Institutional distancing. Institutional distancing is the shielding of organizational members from the monitoring and reinforcing activities of field-level audiences, weakening commitment to the prescriptions that they endorse. In the case of professionals, distancing lowers attachment to the norms and cognitive structures of a particular professional logic by separating professionals from the strictures of professional associations and regulators (Greenwood \& Suddaby, 2006). In this way, institutional distancing allows organizations to weaken the 'representation' of one or more logics within an organization (Pache \& Santos, 2010). Three interrelated dynamics underpin institutional distancing - cosmopolitanism, continuous positive feedback, and structural assurance - and each occurs more readily within rather than across organizations.

Cosmopolitanism, the hiring of professionals who are less tethered to a given way of working, enables practice-driven institutional change by clustering within the organization practitioners who are more open to improvisation and negotiated approaches. The importance of human resource practices as a dynamic that enables change in situations of institutional complexity was highlighted by Battilana and Dorado (2010) who observed that a prerequisite for the blending of logics in a new organization is the recruitment of practitioners with no attachment to the logics involved. In an established organization, however, such an approach is not possible, as practitioners, especially professionals, have pre-existing attachments to an institutional logic. In such situations, selective hiring can filter out professionals with an obdurate commitment to a specific logic and assemble within the organization those whose experiences make them amenable to unfamiliar ways of working. In effect, recruitment enables institutional distancing by clustering professionals predisposed to a given logic.

The predisposition of such professional 'subgroups' (Detert \& Pollock, 2008: 188) is then honed through shared work experiences and training geared to the enactment of a particular logic. In this way, hiring and training practices emulate the isolating effect of 'relational spaces' observed in Kellogg's (2009) hospital study - except that the effect is not achieved in a distinct physical space 
away from work, but in the organization of work. That is, the 'practice' itself, as a set of activities and organizational unit (Anand, Gardner, \& Morris, 2007), becomes the relational space for like-minded professionals who, by their organizational proximity, reinforce their common orientation towards the logic governing their practice and distance themselves from the logic governing their field.

The enabling effect of cosmopolitanism is reinforced through continuous positive feedback, i.e., through repeated and consistent messages from colleagues, superiors, or market participants that practice deviations are effective and appropriate. Uncertainty generated by novel institutional complexity increases the sensitivity of organizational actors to feedback from critical audiences. Not surprisingly, therefore, practitioners seek approval of their improvisations from both internal and external sources which, if received, generates 'deviation amplification' (Plowman et al., 2007: 520). That is, positive feedback encourages and escalates deviations from established norms, whereas negative feedback counteracts deviations. As change follows the most prevalent feedback loop, the balance of positive and negative feedback conditions how quickly adaptations accumulate and how radical deviations will become. Thus, if feedback is consistently in one direction, rather than mixed, it amplifies small improvisations, reinforcing their legitimation and diffusion. This is especially so when positive feedback is continuous, i.e. immediate and repetitive, and is received from a wider network of actors that stretches beyond the original interacting parties. In our case this included the syndicate banks signaling acceptance of the incorporated improvisations, client surveys feeding back personal experiences to a large population of lawyers, and seniors acting as role models for junior associates.

Continuous positive feedback is a particularly important enabling dynamic for reorienting the normative network. In our case, the absence of continuous scrutiny by professional regulators and the low likelihood of examination by courts meant that there was virtually no negative feedback from these field-level agencies and thus no forceful push against the emerging new practice. This one-sidedness of the feedback loop significantly enabled the re-prioritizing of referent audiences. 
Continuous positive feedback of this kind is more likely to occur if the organization can shield its members from proponents of competing logics by providing 'structural assurance' that things are 'safe and fair' (Wilson, Boyer O'Leary, Metiu, \& Jett, 2008: 989). Structural assurance arises from status and is especially apposite in professional settings because it lowers professional concerns that organizational practices and expectations are appropriate, even though they may run counter to institutionalized norms of conduct. It enables elite firms to displace regulatory agencies and act as micro-professions, distancing professionals from the wider professional community to the point where 'identification with the profession and the organization [are] coterminous' (Grey, 1998: 581). In these circumstances the boundary between firm and profession collapses, making it easier for professionals within an organization to accept that the practices and logics they are being asked to adopt are 'professional', i.e. legitimate. Grey (2003), in his study of Arthur Andersen, highlighted this effect, showing how the pressure to maintain and grow a portfolio of high-value clients cajoled accountants to subordinate professional to commercial ideals. The outcome of successful structural assurance, in other words, is an increased ability to persuade professionals to accept the legitimacy of situated improvisations and, more critically, to endorse the normative reorientation that they entail.

Structural assurance not only operates in the relationship between individual practitioners and their organization, but also between practitioners of different organizations interacting through work. Much in the way that Baum and Oliver (1991: 189) note that organizations gain 'legitimacy by association' from ties with exemplary actors, new practices can gain legitimacy if they are associated with an elite firm. Diffusion, as we have observed in the core mechanism of unobtrusive embedding, is not fuelled by a wish to become similar to others, but to become similar to leading organizations. Hence, some ideas become popular 'not primarily because of their properties but because of who transports and supports them' (Sahlin \& Wedlin, 2008: 221).

Structural assurance also has implications for relationships between individual organizations and their regulators. High-status organizations receive less critical scrutiny from regulators because it is 
assumed that they require less oversight. Simultaneously, high-status firms have the benefit of resources - legitimacy, reputation, and revenues - that lessen their dependence vis-à-vis regulators should their norm-breaking improvisations eventually catch the regulator's attention. By virtue of their status, elite firms can initiate and legitimate change simply because they are relatively buffered from the risk and any subsequent costs of breaking with an established norm (Dorado, 2005). Their resources mean that it would be difficult for professional regulators to bluntly oppose them, especially if, as in our case, the resource differential between regulator and regulated is particularly large. Instead, regulators are more likely to endorse practice deviations of elite firms under existing regulation by using any 'theoretical elasticity' in their mandate (Lounsbury \& Crumley, 2007: 1004).

In effect, the resource endowment that comes with status reduces the need to mobilize field-level support for change and thereby enables both the relatively non-conflictual justification of change by reorienting the normative network and its quiet diffusion through unobtrusive embedding. Hence, as depicted by the dashed lines in Figure 1, the enabling dynamics of organizational coordination and institutional distancing affect the operation of all three core mechanisms of practice-driven institutional change and foster the emergence of a consolidated hybrid practice.

\section{Summary}

Practice-driven institutional change differs from existing field-level accounts in terms of its initial locus, its mechanisms, and its unfolding. The above model emphasizes that it is in micro-level practices that field-level logics are enacted, and that it is in their collision that institutional contradictions are experienced and problematized. Novel institutional complexity paired with the urgency and consequence of accomplishing specific tasks, all generated and experienced in the 'doing' of work, provide a strong precipitating push for change. They trigger a chain of mechanisms, starting with efforts to cope through situated improvising. As problematic practices are anchored in supra-organizational logics, these improvising efforts are inextricably intertwined with efforts to pragmatically justify emerging adaptations by reorienting the normative network of audiences from 
whom approval is to be sought. The situatedness of change in ongoing working practice entails that it is pragmatically justified there and then by prioritizing the expectations of a narrow set of referent audiences. Over the course of numerous improvisations, the logic governing the practice begins to shift as some audiences are more consistently observed than others. Then, through interactions with peers outside the organization, practice improvisations and their inherent logic diffuse relatively quietly and become embedded at the field level without attracting the attention of possible resistors. Paradoxically, as practice-driven change accumulates in an apparently uncoordinated and imperceptible manner, its diffusion is harder to observe and therefore less conflictual than that of more dramatic innovations.

These core mechanisms are enabled and amplified by two organizational properties: the impulse of organizational coordination and the capacity for institutional distancing. Organizational coordination, through the bureaucratic impulse inherent to all organizations and assisted by the vertical connectedness of senior staff to 'frontline' activities, facilitates improvisations, reinforces the reorientation of the normative network, and quickens the consolidation and codification of an emerging new practice. Institutional distancing - derived from an organization's status, the provision of continuous positive feedback, and the cosmopolitanism of its workforce - enables all three core mechanisms. Cosmopolitan members are more open to alternative ways of working, continuous positive feedback encourages and amplifies practice deviations, and status provides structural assurance that new activities and solutions are legitimate within and beyond the organization, thereby reducing resistance to the emergence, justification and diffusion of new ways of working.

Importantly, our model does not treat mechanisms in isolation, but highlights their recursive interaction. For instance, the acceptance of situated improvisations depends on their concurrent justification through a reorientation of the normative network. Increasing normative reorientation, in turn, facilitates future improvisations, but also enables unobtrusive embedding, insofar as potential resistors are marginalized. Further, as an emerging practice and its implicit logic become 
unobtrusively embedded, continuous positive feedback reassures practitioners in their improvising and facilitates justification of further departures from the original field-level logic. A distinctive feature of the model, therefore, is the interlinking of the three core mechanisms that connects individual, organization and field levels into a coherent, multi-level model of institutional change

\section{CONCLUSION}

Despite increasing interest in processes of institutional change, an over-emphasis on field-level shocks or contradictions, and on strategically motivated entrepreneurship has limited our understanding of where and how field-level institutional change can originate and how it might unfold. Our model offers a less dramatic, but no less potent, explanation of field-level change. It demonstrates how institutional change can originate in seemingly trivial micro-level responses to the mundane yet pervasive pressure to accomplish work in the face of novel institutional complexity.

Our model also explains the mechanisms by which practice-level adaptations emerge, are justified, consolidate within an organization, and radiate to the level of the field. Importantly, we do not treat these mechanisms in isolation, but demonstrate their 'concatenation' (Tilly, 2001), highlighting how the nature of the origin of change prompts distinct forms of theorization and diffusion. In doing so, we show that these mechanisms mutually reinforce each other, facilitating the accumulation and radicalization of practice-driven change. By explaining this set of mechanisms, their concatenation and recursive interaction, we have produced a more complete, multi-level model of institutional change that connects practice, organization, and field.

Finally, our model gives belated recognition to the critical role of organizational properties that enable and amplify the core mechanisms of practice-driven change. These enabling dynamics shape the way in which institutional demands penetrate the organization and are experienced by practitioners, and influence how quickly practice-level adaptations will consolidate within the organization and move to the level of the field. 
Importantly, the contributions from our multi-level model of practice-driven institutional change are not limited to institutional theory, but extend practice theory as well. Attending to practices that are institutionally anchored outside an organization incorporates the broader cultural and normative contexts that practice theorists have acknowledged, but previously excluded from their empirical work. It extends existing concepts of situated change and improvising by showing how improvisations in institutionalized practices are inextricably intertwined with the ongoing theorization of change as it happens. Likewise, the properties of the organization within which change emerges or is implemented have been largely ignored by practice theorists. They have privileged examination of intra-organizational activities - that is, they have looked inside the organization but not at it. The organization itself, and how it mediates the influence and emergence of institutional structures, has been ignored.

Lastly, when practice is interpreted as 'doing work', it also covers the middle ground between current approaches that view change as the result of strategic planning or as the accidental accumulation of unintentional changes (Plowman et al., 2007). Small changes in working practice are not unintentional, but motivated by the experience of novel institutional complexity. Their accumulation is not accidental or random, but implicitly coordinated by their common purpose and connectedness through participation in practice. Improvisations build upon each other through the 'heedful interrelating of practitioners doing work' (Dorado, 2005: 396). Increased attention by both practice and institutional theorists to work as an important facet of everyday life should lead to more nuanced understandings of intentionality and change.

We have argued that the practice approach offers the possibility of new insights into issues of central concern to institutional analysis. It throws into relief the roles and interactions of multiple actors, how they are wittingly or otherwise engaged in the change process, their motivations for doing so, and how they make sense of the influence of overarching logics through their day-to-day activities. In effect, the approach provides a means for getting at the longstanding concern with the 
paradox of embedded agency (for a review, see Battilana et al., 2009) and the more recent concern with understanding how institutional logics are instantiated and adapted (Thornton \& Ocasio, 2008) - concerns that are central to debates over institutional change.

In advancing a practice approach to institutional change, however, we must be mindful that our findings have been derived from a study of professionals working within one organization, an elite international law firm created by merger. Future research should, therefore, explore whether the observed mechanisms operate in other professions, jurisdictions, or sectors of society - and whether they do so in similar ways to those outlined here.

In pursuing such research, we should be sensitive to the temporal context, organizational context, and the type of practice under investigation. Our case, for instance, highlights the roles and interactions of particular actors - regulators, practice communities, multinational professional service firms - involved in a particular practice that embodies competing institutional logics. It also identifies a relative lack of regulatory pushback, as historical conditions were such that the regulator was initially distracted and hesitant to rebut the deviations of elite firms - and eventually unable to do so. This observation suggests that the relative power of regulators and regulated may be historically contingent and that regulatory agencies may not always be the impartial monitoring and enforcement agents they are widely assumed to be (e.g., Scott, 2008). The role of regulatory agencies appears more complex than typically portrayed. Understanding the specific conditions under, and the means, by which regulators decide to take on resourceful elites once unobtrusive changes become visible, is an empirical question which merits further enquiry.

Our study has shown the important role of the structural context within which a practice may be housed. Organizational coordination, we noted, accelerates and amplifies the change process, facilitating its movement from practice to field. Therefore, future research could probe how various means of coordination - or different combinations of them - enable and/or constrain practicedriven change. In our setting, vertical coordination was enhanced by the highly decentralized and 
participative partnership format distinctive of professional service firms (Malhotra \& Morris, 2009), which has features similar to the 'dynamic delegation' outlined by Klein et al (2006). More hierarchically structured organizations, in contrast, may be less accommodating of practice-level improvisations. Similarly, the loosely-coupled, overlapping project structure of legal work, with its emphasis upon emergent as well as formal coordination devices, facilitated horizontal coordination; more sequentially ordered and tightly coupled arrangements, in contrast, might be less conducive to practice-level improvisation and less able to generate coordination. Recently, there has been a renaissance of interest in how organizations secure collective performance through formal and emergent integrative mechanisms (e.g., Jarzabkowski, Le, \& Feldman, forthcoming; Okhuysen \& Bechky, 2009). Uncovering how differences in such mechanisms affect the processes by which practice-driven change unfolds and moves to the level of the field, or is prevented from doing so, would be an important direction of future research.

Finally, it is also important to remember that not all practices are the same. Practices that are coproduced - as, in our case, by lawyers from different jurisdictions and, critically, demanding and powerful clients - might be more susceptible to improvised adaptation than practices that involve only one particular group of practitioners. It would thus be interesting to examine whether the range and heterogeneity of practitioners engaged in a practice increases the probability of improvisation and alteration. Practices that draw together several professions - as often occurs, for example, in hospitals - may be more exposed to novel institutional complexity and susceptible to improvisation and change, than practices (e.g., an audit) conducted by a single profession. A comparative analysis of practices is overdue.

In conclusion, we surmise that more institutional change than is currently acknowledged in the literature begins at the level of the practice, because even planned institutional change is bound to arise in response to break-downs of institutionalized practices in real-life situations. Yet, institutionalists have chosen to leave this 'coalface' (Barley, 2008) largely idle and have preferred to 
engage with change projects only after they had accumulated and taken recognizable shape in new regulations or organizational forms. Our model, in contrast, demonstrates the value of injecting a stronger dose of practice theory into current institutional arguments in order to bring closer together concepts and levels of analysis that have previously been kept relatively separate. By taking seriously that field-level institutional logics are enacted and transformed in the mundane activities of individuals and in response to the localized demands of situated activity, the practice perspective helps institutional theorists refine explanations of endogenous change and develop a much-needed multi-level understanding of individual human agency in highly institutionalized arenas. 


\section{REFERENCES}

Anand, N. \& Watson, M. R. 2004. Tournament rituals in the evolution of fields: The case of the Grammy awards. Academy of Management Journal, 47(1): 59-80.

Anand, N., Gardner, H., \& Morris, T. 2007. Knowledge based innovation: Emergence and embedding of new practice areas in management consulting firms. Academy of Management Journal, 50(2): 406-428.

Ansari, S. \& Phillips, N. 2011. Text me! New consumer practices and change in organizational fields. Organization Science, 22(6): 1579-1599.

Avenarius, H. 1997. Die Rechtsordnung der Bundesrepublik Deutschland: Eine Einführung. Bonn: Bundeszentrale für politische Bildung.

Barley, S. R. \& Tolbert, P. S. 1997. Institutionalization and structuration: Studying the links between action and institution. Organization Studies, 18(1): 93-118.

Barley, S. R. 2008. Coalface institutionalism. In R. Greenwood \& C. Oliver \& K. Sahlin \& R. Suddaby (Eds.), The Sage handbook of organizational institutionalism: 490-515. London: Sage.

Battilana, J., Leca, B., \& Boxenbaum, E. 2009. How actors change institutions: Towards a theory of institutional entrepreneurship. The Academy of Management Annals, 3(1): 65-107.

Battilana, J. \& Dorado, S. 2010. Building sustainable hybrid organizations: The case of commercial microfinance organizations. Academy of Management Journal, 53(6): 1419-1440.

Baum, J. A. C. \& Oliver, C. 1991. Institutional linkages and organizational mortality. Administrative Science Quarterly, 36(2): 187-218.

Benda, E. 1981. Anwaltschaft und Bundesverfassungsgericht. München: C.H. Beck.

Binder, A. 2007. For love and money: Organizations' creative responses to multiple environmental logics. Theory \& Society, 36(6): 547-571.

BRAK. 2007. Deutsches Berufstecht und internationale Anwaltssozietäten: Tätigkeitsbericht des Ausschusses 'Internationale Sozietäten' der Bundesrechtsanwaltskammer. Berlin: Bundesrechtsanwaltskammer.

Brint, S. \& Karabel, J. 1991. Institutional origins and transformations: The case of American community colleges. In W. W. Powell \& P. J. DiMaggio (Eds.), The new institutionalism in organizational analysis: 337-360. Chicago, IL: University of Chicago Press.

Brint, S. 1994. In an age of experts: The changing role of professionals in politics and public life. Princeton, NJ: Princeton University Press.

Chreim, S., Williams, B. E., \& Hinings, C. R. 2007. Interlevel influences on the reconstruction of professional role identity. Academy of Management Journal, 50(6): 1515-1539.

Clemens, E. S. \& Cook, J. M. 1999. Politics and institutionalism: Explaining durability and change. Annual Review of Sociology, 25(1): 441-466. 
Delbridge, R. \& Edwards, T. 2008. Challenging conventions: Roles and processes during nonisomorphic institutional change. Human Relations, 61(3): 299-325.

Delmestri, G. 2006. Streams of inconsistent institutional influences: Middle managers as carriers of multiple identities. Human Relations, 59(11): 1515-1541.

Den Hond, F. \& De Bakker, F., G.A. 2007. Ideologically motivated activism: How activist groups influence corporate social change activities. Academy of Management Review, 32(3): 901-924.

Detert, J. R. \& Pollock, T. G. 2008. Values, interests, and the capacity to act: Understanding professionals' responses to market-based improvement initiatives in highly institutionalized organizations. Journal of Applied Behavioral Science, 44(2): 186-214.

Deutscher Bundestag. 2008. Aktueller Begriff: Rechtsdienstleistungsgesetz; http://www.bundestag.de/dokumente/analysen/2008/rechtsdienstleistungsgesetz.pdf; 23 January, 2011.

DiMaggio, P. 1988. Interest and agency in institutional theory. In L. G. Zucker (Ed.), Institutional patterns and organizations: Culture and environment. 3-21. Cambridge, MA: Ballinger.

DiMaggio, P. J. \& Powell, W. W. 1983. The iron cage revisited: Institutional isomorphism and collective rationality in organizational fields. American Sociological Review, 48(2): 147-160.

Djelic, M.-L. \& Quack, S. 2003. Conclusion: Globalization as a double process of institutional change and institution building. In M. L. Djelic \& S. Quack (Eds.), Globalization and institutions: 302-334. Cheltenham: Edward Elgar.

Dobbin, F. 1992. The origins of private social insurance: Public policy and fringe benefits in America, 1920-1950. American Joumal of Sociology, 97: 1416-1450.

Dobbin, F. 2009. Inventing equal opportunity. Princeton, NJ: Princeton University Press.

Dorado, S. 2005. Institutional entrepreneurship, partaking and convening. Organization Studies, 26(3): 385-414.

Edelman, L. B. 1990. Legal environments and organizational governance: The expansion of due process in the American workplace. The American Journal of Sociology, 95(6): 1401-1440.

Edelman, L. B. 1992. Legal ambiguity and symbolic structures: Organizational mediation of civil rights law. American Joumal of Sociology, 97(6): 1531-1576.

Eisenhardt, K. M. \& Graebner, M. E. 2007. Theory building from cases: Opportunities and challenges. Academy of Management Journal, 50(1): 25-32.

Emirbayer, M. \& Mische, A. 1998. What is agency? The American Journal of Sociology, 103(4): 962-1023.

Feldman, M. S. 2000. Organizational routines as a source of continuous change. Organization Science, 11(6): 611-629. 
Friedland, R. \& Alford, R. R. 1991. Bringing society back in: Symbols, practices and institutional contradictions. In W. W. Powell \& P. DiMaggio (Eds.), The new institutionalism in organizational analysis: 232-263. Chicago, IL: University of Chicago Press.

Garud, R., Jain, S., \& Kumaraswamy, A. 2002. Institutional entrepreneurship in the sponsorship of common technological standards: The case of Sun Microsystems and Java. Academy of Management Joumal, 45(1): 196-214.

Garud, R. 2008. Conferences as venues for the configuration of emerging organizational fields: The case of cochlear implants. Journal of Management Studies, 45(6): 1061-1088.

Greenwood, R. \& Hinings, C. R. 1996. Understanding radical organizational change: Bringing together the old and the new institutionalism. Academy of Management Review, 21(4): 10221054.

Greenwood, R., Suddaby, R., \& Hinings, C. R. 2002. Theorizing change: The role of professional associations in the transformation of institutionalized fields. Academy of Management Journal, 45(1): 58-80.

Greenwood, R. \& Suddaby, R. 2006. Institutional entrepreneurship in mature fields: The big five accounting firms. Academy of Management Journal, 49(1): 27-48.

Greenwood, R., Magàn Diaz, A., Li, S., \& Céspedes Lorente, J. 2010. The multiplicity of institutional logics and the heterogeneity of organizational responses. Organization Science, 21(2): 521-539.

Greenwood, R., Raynard, M., Kodeih, F., Micellota, E., \& Lounsbury, M. 2011. Institutional complexity and organizational responses. Annals of the Academy of Management, 5(1): 1 -55.

Grey, C. 1998. On being a professional in a "Big six" Firm. Accounting, Organizations and Society, 23(5-6): 569-587.

Grey, C. 2003. The real world of Enron's auditors. Organization, 10(3): 572-576.

Hallett, T. 2010. The myth incarnate: Recoupling processes, turmoil, and inhabited institutions in an urban elementary school. American Sociological Review, 75(1): 52-74.

Halliday, T. \& Karpik, L. (Eds.). 1998. Lawyers and the rise of Western political liberalism. Oxford: Oxford University Press.

Hardy, C. \& Maguire, S. 2008. Institutional entrepreneurship. In R. Greenwood \& C. Oliver \& K. Sahlin \& R. Suddaby (Eds.), The Sage handbook of organizational institutionalism: 198-217: Sage.

Hargrave, T. J. \& Van de Ven, A. H. 2006. A collective action model of institutional innovation. Academy of Management Review, 31(4): 864-888.

Heimer, C. A. 1999. Competing institutions: Law, medicine, and family in neonatal intensive care. Law \& Society Review, 33(1): 17-66.

Hensmans, M. 2003. Social movement organizations: A metaphor for strategic actors in institutional fields. Organization Studies, 24(3): 355-381. 
Hermann, C. F. 1963. Some consequences of crisis which limit the viability of organizations. Administrative Science Quarterly, 8: 343-358.

Hoffman, A. J. 1999. Institutional evolution and change: Environmentalism and the US chemical industry. Academy of Management Journal, 42(4): 351-371.

Jarzabkowski, P. 2005. Strategy as practice: An activity-based approach. London: Sage.

Jarzabkowski, P. 2008. Shaping strategy as a structuration process. Academy of Management Journal, 51(4): 621-650.

Jarzabkowski, P., Matthiesen, J., \& Van de Ven, A. 2009. Doing which work? A practice approach to institutional pluralism. In T. B. Lawrence \& R. Suddaby \& B. Leca (Eds.), Institutional work: Actors and agency in institutional studies of organizations: 284-316. Cambridge: Cambridge University Press.

Jarzabkowski, P., Le, J. K., \& Feldman, M. forthcoming. Toward a theory of coordinating: Creating coordinating mechanisms in practice Organization Science.

Keillmann, A. 2006. The Einheitsjurist: A German phenomenon. German Law Journal, 3: 293312.

Kellogg, K. C., Orlikowski, W. J., \& Yates, J. 2006. Life in the trading zone: Structuring coordination across boundaries in postbureaucratic organizations. Organization Science, 17(1): 2244.

Kellogg, K. C. 2009. Operating room: Relational spaces and microinstitutional change in surgery. American Journal of Sociology, 115(3): 657-711.

Klein, K. J., Ziegert, J. C., Knight, A. P., \& Xiao, Y. 2006. Dynamic delegation: Shared, hierarchical, and deindividualized leadership in extreme action teams. Administrative Science Quarterly, 51 (4): 590-621.

Kostova, T., Roth, K., \& Dacin, T. 2008. Institutional theory in the study of multinational corporations: A critique and new directions. Academy of Management Review, 33(4): 994-1006.

Kraatz, M. S. \& Moore, J. 2002. Executive migration and institutional change. Academy of Management Journal, 45(1): 120-143.

Kramer, R. M. \& Lewicki, R. J. 2010. Repairing and enhancing trust: Approaches to reducing organizational trust deficits The Academy of Management Annals, 4(1): 245-277.

Langley, A. 1999. Strategies for theorizing from process data. Academy of Management Review, 24(4): 691-710.

Lawrence, T. B., Hardy, C., \& Phillips, N. 2002. Institutional effects of interorganizational collaboration: The emergence of proto-institutions. Academy of Management Journal, 45(1): 281290.

Lawrence, T. B. \& Suddaby, R. 2006. Institutions and institutional work. In S. Clegg \& C. Hardy \& T. Lawrence \& W. Nord (Eds.), The Sage handbook of organization studies: 215-253. London: Sage. 
Lawrence, T. B., Suddaby, R., \& Leca, B. 2009. Introduction: Theorizing and studying institutional work. In T. Lawrence \& R. Suddaby \& B. Leca (Eds.), Institutional work: Actors and agency in institutional studies of organizations: 1-28. Cambridge: Cambridge University Press.

Leblebici, H., Salancik, G. R., Copay, A., \& King, T. 1991. Institutional change and the transformation of interorganizational fields: An organizational history of the US radio broadcasting industry. Administrative Science Quarterly, 36(3): 333-363.

Leca, B. \& Naccache, P. 2006. A critical realist approach to institutional entrepreneurship. Organization, 13(5): 627-651.

Locke, K. D. 2001. Grounded theory in management research. London: Sage.

Lounsbury, M. 2002. Institutional transformation and status mobility: The professionalization of the field of finance. Academy of Management Joumal, 45(1): 255-266.

Lounsbury, M. 2007. A tale of two cities: Competing logics and practice variation in the professionalizing of mutual funds. Academy of Management Journal, 50(2): 289-307.

Lounsbury, M. \& Crumley, E. T. 2007. New practice creation: An institutional perspective on innovation. Organization Studies, 28(7): 993-1012.

Maguire, S., Hardy, C., \& Lawrence, T. 2004. Institutional entrepreneurship in emerging fields: HIV/AIDS treatment advocacy in Canada. Academy of Management Journal, 47(5): 657-679.

Maguire, S. \& Hardy, C. 2009. Discourse and deinstitutionalization: The decline of DDT. Academy of Management Journal, 52(1): 148-178.

Malhotra, N. \& Morris, T. 2009. Heterogeneity in professional service firms. Journal of Management Studies, 46(6): 895-922.

March, J. G. 1981. Footnotes to organizational change. Administrative Science Quarterly, 26(4): 563-577.

Marshall, C. \& Rossman, G. B. 1999. Designing qualitative research. London: Sage.

Meyer, J. W. \& Rowan, B. 1977. Institutionalized organizations: Formal structure as myth and ceremony. American Journal of Sociology, 83(2): 340-363.

Morgan, G. \& Quack, S. 2005. Institutional legacies and firm dynamics: The growth and internationalization of UK and German law firms. Organization Studies, 26(12): 1765-1785.

Okhuysen, G. A. \& Bechky, B. A. 2009. Coordination in organizations: An integrative perspective. The Academy of Management Annals, 3(1): 463-502.

Orlikowski, W. J. 1996. Improvising organizational transformation over time: A situated change perspective. Information Systems Research, 7(1): 63-92.

Orlikowski, W. J. 2002. Knowing in practice: Enacting a collective capability in distributed organizing. Organization Science, 13(3): 249-273.

Pache, A. \& Santos, F. 2010. When worlds collide: The internal dynamics of organizational responses to conflicting institutional demands. Academy of Management Joumal, 35(3): 455-476. 
Plowman, D. A., Baker, L. T., Beck, T. E., Kulkarni, M., Solansky, S. T., \& Travis, D. V. 2007. Radical change accidentally: The emergence and amplification of small change. Academy of Management Joumal, 50(3): 515-543.

Powell, W. W. \& Colyvas, J., A. 2008. Microfoundations of institutional theory. In R. Greenwood \& C. Oliver \& K. Sahlin-Andersson \& R. Suddaby (Eds.), The Sage handbook of organizational institutionalism: 276-298. London: Sage.

Pratt, M. G., Rockmann, K. W., \& Kaufmann, J. B. 2006. Constructing professional identity: The role of work and identity learning cycles in the customization of identity among medical residents. Academy Of Management Journal, 49(2): 235-262.

Quack, S. 2007. Legal professionals and transnational law-making: A case of distributed agency. Organization, 14(5): 643-666.

Rao, H., Morrill, C., \& Zald, M. N. 2000. Power plays: How social movements and collective action create new organizational forms. Research in Organizational Behavior, 22: 237-283.

Rao, H., Monin, P., \& Durand, R. 2003. Institutional change in Toque Ville: Nouvelle cuisine as an identity movement in French gastronomy. American Joumal of Sociology, 108(4): 795-843.

Rao, H. \& Kenney, M. 2008. New forms as settlements. In R. Greenwood \& C. Oliver \& K. Sahlin \& R. Suddaby (Eds.), The Sage handbook of organizational institutionalism: 352-370. London: Sage.

Reay, T. \& Hinings, C. R. 2005. The recomposition of an organizational field: Health care in Alberta. Organization Studies, 26(3): 351-384.

Reay, T., Golden-Biddle, K., \& Germann, K. 2006. Legitimizing a new role: Small wins and microprocesses of change. Academy of Management Journal, 49(5): 977-998.

Reay, T. \& Hinings, C. R. 2009. Managing the rivalry of competing institutional logics. Organization Studies, 30(6): 629-652.

Rhodes, T., Campbell, M., \& Dawson, C. (Eds.). 2004. Syndicated lending: Practice and documentation. London: Euromoney Books.

Sahlin-Andersson, K. \& Engwall, L. (Eds.). 2002. The expansion of management knowledge: Carriers, flows and sources. Stanford, CA: Stanford Business Books.

Sahlin, K. \& Wedlin, L. 2008. Circulating ideas: Imitation, translation and editing. In R. Greenwood \& C. Oliver \& K. Sahlin \& R. Suddaby (Eds.), The Sage handbook of organizational institutionalism: 218-242. London: Sage.

Schatzki, T. R. 2001. Introduction: Practice theory. In T. R. Schatzki \& K. Knorr-Cetina \& E. v. Savigny (Eds.), The practice turn in contemporary theory. 1-14. London: Routledge.

Schneiberg, M. \& Lounsbury, M. 2008. Social movements and institutional analysis. In R. Greenwood \& C. Oliver \& K. Sahlin \& R. Suddaby (Eds.), The Sage handbook of organizational institutionalism: 650-672. London: Sage.

Scott, W. R. 2008. Lords of the dance: Professionals as institutional agents. Organization Studies, 29(2): 219-238. 
Seo, M.-G. \& Creed, W. E. D. 2002. Institutional contradictions, praxis, and institutional change: A dialectical perspective. Academy of Management Review, 27(2): 222-247.

Solicitors Regulatory Authority. 2007. Solicitors code of conduct 2007: Guidance notes. London: Solicitors Regulation Authority.

Stake, R. E. 1995. The art of case study research. Thousand Oaks, CA: Sage.

Strang, D. \& Meyer, J. W. 1993. Institutional conditions for diffusion. Theory and Society, 22(4): 487-511.

Suddaby, R. \& Greenwood, R. 2005. Rhetorical strategies of legitimacy. Administrative Science Quarterly, 50(1): 35-67.

Suddaby, R. 2006. From the editors: What grounded theory is not. Academy of Management Journal, 49(4): 633-642.

The Economist. 2004. Trying to get the right balance: Special report international law firms. The Economist, 370: 79-82.

Thompson, J. D. 1967. Organizations in action: Social science bases of administrative theory. New York: McGraw-Hill.

Thornton, P. 2004. Markets from culture: Institutional logics and organizational decisions in higher educational publishing. Stanford, CA: Stanford University Press.

Thornton, P. H., Jones, C., \& Kury, K. 2005. Institutional logics and institutional change in organizations: Transformation in accounting, architecture, and publishing. In M. Lounsbury (Ed.), Transformation in cultural industries: 125-170. Amsterdam: Elsevier.

Thornton, P. H. \& Ocasio, W. 2008. Institutional logics. In R. Greenwood \& C. Oliver \& K. Sahlin-Andersen \& R. Suddaby (Eds.), The Sage handbook of organizational institutionalism: 99-129. London: Sage.

Tilly, C. 2001. Mechanisms in political processes. Annual Review of Political Science, 4: 21-41

Tracey, P., Phillips, N., \& Jarvis, O. 2011. Bridging institutional entrepreneurship and the creation of new organizational forms: A multilevel model. Organization Science, 22(1): 60-80.

Tsoukas, H. \& Chia, R. 2002. On organizational becoming: Rethinking organizational change. Organization Science, 13(5): 567-582.

von Nordenflycht, A. 2010. What is a professional service firm? Toward a theory and taxonomy of knowledge-intensive firms. Academy of Management Review, 35(1): 155-174.

Weber, K., Heinze, K., L., \& DeSoucey, M. 2008. Forage for thought: Mobilizing codes in the movement for grass-fed meat and dairy products. Administrative Science Quarterly, 53(3): 529567.

Whittington, R. 2006. Completing the practice turn in strategy research. Organization Studies, 27(5): 613-634. 
Wilson, J. M., Boyer O'Leary, M., Metiu, A., \& Jett, Q. R. 2008. Perceived proximity in virtual work: Explaining the paradox of far-but-close. Organization Studies, 29(7): 979-1002.

Zajac, E. J. \& Westphal, J. D. 1996. Director reputation, CEO-board power, and the dynamics of board interlocks. Administrative Science Quarterly, 41(3): 507-529.

Zilber, T. B. 2002. Institutionalization as an interplay between actions, meanings, and actors: The case of a rape crisis center in Israel. Academy of Management Journal, 45(1): 234-254. 
TABLE 1:

Chronology of Key Events and Research Progress

\begin{tabular}{|c|c|c|}
\hline Year & Developments in economy, legal market and Justitia & Data Sources and Amount \\
\hline $1990 \mathrm{~s}$ & $\begin{array}{l}\text { - Deregulation and globalization of finance flows } \\
\text { - Demand for syndicated finance soars in post-reunification Germany } \\
\text { - Loan Market Association (LMA) founded (1996) } \\
\text { - UK branch of Justitia opens a German office }\end{array}$ & \\
\hline $\begin{array}{r}\text { early } \\
2000 \mathrm{~s}\end{array}$ & $\begin{array}{l}\text { - Emergence of first 'global' law firms (2000) } \\
\text { - Justitia's Anglo-German merger } \\
\text { - German Federal Bar (BRAK) initiates Working Party on int. law firms (2001) } \\
\text { - True Sale Initiative (TSI) founded (2004) }\end{array}$ & $\begin{array}{l}\text { - Awareness of paradox of 'global' firms in an institutionalized, localized sector (2003) } \\
\text { - Access negotiations with Justitia (2004) }\end{array}$ \\
\hline 2005 & $\begin{array}{l}\text { - First meeting between BRAK Working Party on international law firms and } \\
\text { international law firm representatives } \\
\text { - Initial consultations over proposed new Legal Services Bill in Germany } \\
\text { - Justitia begins to codify cross-border best-practice in workshop among European banking } \\
\text { specialists }\end{array}$ & $\begin{array}{l}\text { Pilot Interviews (12 interviews, } 10 \text { hrs of recording) } \\
\text { - } 12 \text { lawyers } \\
\text { Work-based Observations ( } 600 \text { pages of notes, } 40 \text { pages methods reflections) } \\
\text { - } 16 \text { English solicitors in London } \\
\text { - } 13 \text { English solicitors in Frankfurt } \\
\text { - } 13 \text { German Rechtsanwälte in Frankfurt } \\
\text { Workshop Observation I ( } 25 \text { pages of notes) } \\
\text { - } 22 \text { European banking specialists }\end{array}$ \\
\hline 2006 & $\begin{array}{l}\text { - BRAK Working Party continues dialogue with international law firms through } \\
\text { quarterly events }\end{array}$ & $\begin{array}{l}\text { Formal Interviews ( } 50 \text { interviews, } 48 \text { hrs of recordings) } \\
\text { - } 17 \text { English solicitors in London } \\
\text { - } 16 \text { English solicitors in Frankfurt } \\
\text { - } 17 \text { German Rechtsanwälte in Frankfurt } \\
\text { Workshop Observation II } \\
\text { - } 25 \text { German law graduates and } 10 \text { senior lawyers } \\
\text { Elite Interviews ( } 5 \text { interviews, } 7 \text { hrs of recordings) } \\
\text { - Senior partner, former managing partner, founding members of the German office, } \\
\text { global head of the banking group }\end{array}$ \\
\hline 2007 & $\begin{array}{l}\text { - German-law LMA template published } \\
\text { - BRAK Working Party declares international practice as 'testing the limits' of } \\
\text { professional law, but endorses its client-service logic }\end{array}$ & $\begin{array}{l}\text { Archival Materials } \\
\text { - Internal private documents (e.g., annotated contracts, training materials, guidelines, deal } \\
\text { reviews) } \\
\text { - Internal public documents (e.g., website, recruitment brochures, client newsletters) } \\
\text { - External public documents (e.g., reports, training guidelines, textbooks, Law Society Gazette } \\
\text { ('90-'07), BRAK Mitteilungen ('90-'07), The Lanyer 98-'07), JUVE Rechtsmarkt ('98-'07) }\end{array}$ \\
\hline
\end{tabular}

- German Legal Services Act introduces legal service as key term 
TABLE 2:

Summary of Core Concepts, Empirical Themes and Illustrative Data

CONTEXT

Field-level

institutional

complexity

Collision of local

practices

\section{Cross-national variation in legal regimes, professional logics and working practices}

In Germany you have your duty to the court first and foremost. In England you have your duty to your client. And that's almost just like the inverse.

[In Germany] everybody just relied on the civil code, regardless of whether it produced the right answer or not - or the commercially desired answer.

It is unrealistic to harmonize professional laws even in the mid-term. Differences in national professional laws and especially differences in their understanding of the position and function of lawyers [in society] are too big to do so.

\section{Local ways of working clashing in international syndicated finance transactions}

The English approach is very pragmatic, commercial, whereas the Germans tend to be a bit more academic in their approach.

I definitely was surprised in the workgroup that there were people saying: 'Well you just can't do that.' And, maybe I don't appreciate what you really can't do under whatever continental law, but, I mean, I would never say that.

I find my German colleagues are ... very, very good at identifying issues, at identifying problems. But it is not as evident that the next step in their thinking is putting forward a commercially viable solution to those problems.

\section{PrecipitaTING DYNAMics}

Novel

institutional

complexity

Urgency

Consequence

\section{Experience of institutional alternatives as local practices collide in international syndicated finance transactions}

And when you've just experienced the possibility that there are different ways to do things [...] it will just stop you falling into that kind of complacency trap of just assuming that every legal system in the world works exactly the same as your own, I think.

Clients tend to see the transaction as the same around the world. And on the surface it is: You hand the money over, you take the shares .... Underneath the surface, the lawyer is a bit like the proverbial swan. Whilst the clients are gliding majestically along the water, metaphorically, beneath the surface, the lawyers are running around very quickly, overcoming the local difficulties and homogenizing the market.

Time pressure to 'get the deal done' quickly to satisfy clients and prove the viability of the 'global firm' model

Clients want to close this transaction. ... And any steps in between, they aren't actually all that much concerned about.

A big financial issue which would have been taken care of had we been involved, had been overlooked. The problem was: At [Justitia] we have a global network and for the client it was difficult to understand that in fact this issue was not pointed out at the first stage.

\section{costs of failure (financial and reputationat) amplifying pressure to}

As a client I'm not prepared to pay someone to tell me what I can and can't do. As a client I want someone to come and say: 'OK, I understand what you want to do. It doesn't really work as you want it to work, but here's a solution to get exactly the same result.

The last thing you want is for your client to turn around and say 'That law firm has made life difficult for me. I don't want to deal with them ever again'.

\section{CORE MECHANISMS}

Situated

improvising
Coping with complexity: Working around legal obstacles to 'get the deal done'

So it's probably also creative legal thinking: What are the options under [local] law then to achieve the same result? And yes, the economics of the deal stay largely the same, but it's just making good use of the available rules to overcome any legal issues.

You know 'no' isn't generally an answer and so that will dictate a lot of the day-to-day work. 
Reorienting the Deciding 'who matters': Audiences considered (or not) in justification of improvised solutions

normative network Of course there is a foreign influence on the German legal market, but I can't try to tap a certain market that offers me certain economic conditions without otherwise following the rules of the game in that market.

Sometimes there will then be direct negotiations between the rating agencies and the clients, but generally speaking, their comments are accepted because they are in such a powerful and important position.

Nobody is really relying on the general operation of law. Not in large, negotiated deals like this.

Unobtrusive

embedding

\section{Radiating from practice to field: Practice engagement as key diffusion mechanism}

We often deal with the same people and other law firms, but while we might be advising two or four banks there might be twenty banks involved in the syndication. So those banks will have all the documentation.

It's like a spiral. Standardisation means more deals. More deals mean more experience and more experience can lead to the creation of market expectations.

\section{ENABLING DYNAMICS}

Organizational

coordination

distancing
Facilitating consolidation of new practice through bureaucratic impulse and connectedness within a single firm

Unless you have that constant interaction with your colleagues, it's harder to develop the ability to spot where you might need to be speaking to them. So the more you have ongoing discussions with them, the more you will then do by yourself without having to go and ask [foreign colleagues] every five minutes what you can and can't be doing.

(Demonstrating functionality of Justitia's on-line tool) You select your jurisdictions, issues, overviews: 'security', 'transferability of loans and security', that's a good one. And then you have a comparative table, click on 'go' ... there you go, there is your comparative table that you can then look up on screen.

\section{Facilitating improvising and normative reorienting through cosmopolitanism, feedback, and status}

Many of the Rechtsanwälte in an international firm have their own personal international experiences that they seek to apply.

And for a career: I think if you constantly get pretty good feedback from clients that is certainly an element that is very positive when partners assess your position within the firm.

There is the Bar ...for example, in my entire career, which is now 7 years, I have had no contact with the Bar ... Because what we do is quite 'whacky'. The majority of lawyers don't do this business. It's really only the big ones.

In certain areas we are 'leading' together with other firms. And we set standards as to what you do or don't do in certain areas, purely in terms of contract design, from a practical perspective.

OUTCOME OF CHANGE

Consolidated

hybrid practice

Consolidated hybrid practice as codified in 'best practice' guidelines and online tools

...because so many of [our deals] are cross-border and two or three offices are involved ... [we] have found a sort of lingua franca in which to communicate and do the deals, which is sort of a hybrid amalgam of how each of them did it locally.

Most of the English lawyers over the years have become more German, and most of the German lawyers have become more English in the way of doing deals and of transacting.

Field-level

endorsement of

logic shift

\section{Recognition and acceptance of new professional logic in Germany}

On a large scale, the self-conception of lawyers has turned from a professional as warden of the public weal to a purely profit-oriented service provider.

These days, legal advice is defined as a service offering in a competitive marketplace, the legal profession as provider of these services. 
TABLE 3:

Professional Logics and their Enactment in Practice

Dominant professional logic

\section{Elements of practice enacting the professional logic}

Role identity

Key referent audience

\section{Approach to lega} problems

\section{Approach to drafting}

\section{- Expertise/client-service logic}

As self-regulated professionals, client-facing solicitors are governed by an 'expertise' logic which links professional status to client service.

- Business-oriented legal advisor

As business-oriented legal advisors, solicitors seek to further clients' commercial interests and add value to their business by advising on the management of legal risk.

\section{- Clients and financial markets}

The 'duty to client' implicit in the expertise logic makes clients and the financial markets in which they operate key referents for solicitors' work.

\section{- Pragmatic problem-solving}

Solicitors pragmatically resolve legal problems on behalf of their clients by exploiting the room for manoeuvre afforded by piecemeal case law.

\section{- Comprehensive documenting}

Solicitors comprehensively document every clause and remedy, creating self-contained 'systems of law' that reflect their clients' interests. They produce lengthy, stand-alone documents of up to several hundred pages per transaction.
- Expertise/client-service logic

The blend of traditionally local English and German activities is subsumed under a common expertise logic that privileges client service.

\section{- Business-oriented legal advisor}

Adding value and furthering client interests becomes critical to lawyers in both jurisdictions. Technical excellence is taken as a given and no longer critical to professional role identity.

\section{- Clients and financial markets}

Shifting focus on client service and advisory work for business prioritizes clients and financial markets as key referents and shields work from scrutiny by courts.

\section{- Analytically-informed improvising}

Approaches blend, as solicitors accept civillaw constraints and introduce an initial 'local-law due diligence' to spot legal problems whilst Rechtsanwälte join in improvising pragmatic ways around them.

\section{- Customized blending}

German lawyers broadly move to the English approach, drafting comprehensive, stand-alone documents. They expand their drafting repertoire, learning to customize their drafting to client preferences, blending both approaches in documents that explicate all key terms, but imply standard fundamentals to save length.

\section{- Fiduciary logic}

As a state-sponsored profession, Rechtsanwälte are governed by a 'fiduciary' logic, which links professional status to public service.

\section{- Technical specialist}

Trained as judges and focused on academic learning, Rechtsanwällte are socialized as technical specialists, passing unbiased expert judgement with little regard for commercial implications.

\section{- Judiciary}

The 'duty to court' implicit in the fiduciary logic and the constraints of codified statutes with which agreements must comply make courts the key referent for legal work.

\section{- Forensic analysing}

Rechtsanwälte focus on forensic analysis of contracts and unbiased explanation of the state of law, concerned with problem-finding rather than problem-solving.

\section{- Selective signposting}

Rechtsanwälte 'imply' fundamental terms of codified statutes in their documents and only selectively signpost where parties agree to deviate from these standards. They produce brief documents which have to be read in light of overarching, implied legal statutes. 
FIGURE 1:

From Practice to Field: A Multi-level Model of Practice-Driven Institutional Change

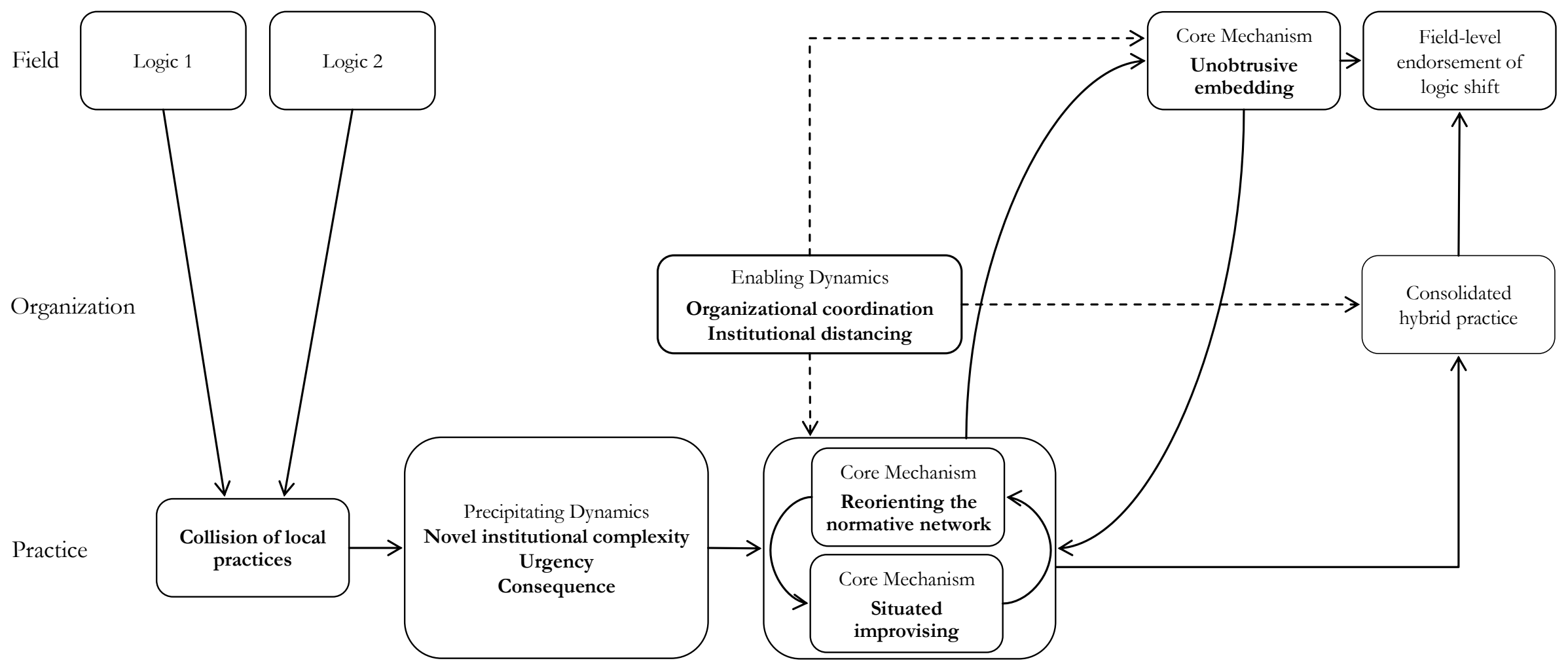


Michael Smets (m.smets@aston.ac.uk) is a Lecturer in Strategy at Aston Business School, Birmingham (UK). He received his D.Phil. from the Saïd Business School, University of Oxford. His research focuses on the interplay of work and institutions in professional contexts. He uses ethnographic approaches to understand how professional firms and professionals at work generate, respond to, and resolve institutional complexity.

Tim Morris (tim.morris@sbs.ox.ac.uk) is a Professor of Management Studies at Saïd Business School, University of Oxford. He received his Ph.D. from the London School of Economics. His research focuses on the political and structural implications of diversifying into new domains for professions and professional firms.

Royston Greenwood (royston.greenwood@ualberta.ca) is the Telus Professor of Strategic Management at the University of Alberta, Canada and Visiting Professor at the Said Business School, University of Oxford. He received his doctorate from the University of Birmingham (UK). His current research interests focus upon the responses of organizations to institutional complexity. He is also studying the role of institutional processes in the concealment of corporate illegality. His preferred research context involves professional service firms. 